\title{
Physical and biogeochemical transports structure in the North Atlantic subpolar gyre
}

\author{
Marta Álvarez and Fiz F. Pérez \\ Instituto de Investigaciones Marinas (CSIC), Vigo, Spain \\ Harry Bryden \\ Southampton Oceanography Centre, Southampton, UK
}

Aida F. Ríos

Instituto de Investigaciones Marinas (CSIC), Vigo, Spain

Received 25 June 2003; revised 18 November 2003; accepted 2 January 2004; published 17 March 2004.

[1] Physical (mass, heat, and salt) and biogeochemical (nutrients, oxygen, alkalinity, total inorganic carbon, and anthropogenic carbon) transports across the transoceanic World Ocean Circulation Experiment (WOCE) A25 section in the subpolar North Atlantic (4x line) obtained previously [Alvarez et al., 2002, 2003] are reanalyzed to describe their regional and vertical structure. The water mass distribution in the section is combined with the transport fields to provide the relative contribution from each water mass to the final transport values. The water mass circulation pattern across the section is discussed within the context of the basin-scale thermohaline circulation in the North Atlantic. Eastern North Atlantic Central, influenced Antarctic Intermediate, Mediterranean, and Subarctic Intermediate Waters flow northward with 10.3, 5.6, 1.7, and $2.9 \mathrm{~Sv}$, respectively. The total flux of Lower Deep Water (LDW) across the section is $1 \mathrm{~Sv}$ northward. A portion of LDW flowing northward in the Iberian Basin recirculates southward within the eastern basin and about $0.7 \mathrm{~Sv}$ flow into the western North Atlantic. About $7 \mathrm{~Sv}$ of Labrador Seawater (LSW) from the Labrador Sea cross the 4x section within the North Atlantic Current, and 12 Sv of LSW from the Irminger Sea flow southward within the East Greenland Current. Denmark Strait Overflow Water flows over the western flank of the Irminger basin $(1.5 \mathrm{~Sv})$, and Iceland Scotland Overflow Water (ISOW) is mainly transported in the Charlie Gibbs Fracture Zone (6 Sv). ISOW remnants flow southward to the eastern basin, contributing to the eastern basin deep ventilation. LSW and the overflows transport $\mathrm{C}_{\mathrm{ANT}}$ southward across the section. This southward $\mathrm{C}_{\mathrm{ANT}}$ transport is overcome by the northward transport in upper layers; finally, $\mathrm{C}_{\mathrm{ANT}}$ is injected into the subpolar gyre where it accumulates. INDEX TERMS: 4532 Oceanography: Physical: General circulation; 4536 Oceanography: Physical: Hydrography; 4805 Oceanography: Biological and Chemical: Biogeochemical cycles (1615); KEYWORDS: subpolar North Atlantic, physical and biogeochemical transports, mixing analysis

Citation: Álvarez, M., F. F. Pérez, H. Bryden, and A. F. Ríos (2004), Physical and biogeochemical transports structure in the North Atlantic subpolar gyre, J. Geophys. Res., 109, C03027, doi:10.1029/2003JC002015.

\section{Introduction}

[2] The relevance of the North Atlantic Ocean and concretely the subpolar gyre within the global thermohaline circulation has been widely proven [e.g., Dickson and Brown, 1994; Schmitz and McCartney, 1993; Schmitz, 1996]. Briefly, the subpolar North Atlantic constitutes an area of deep and mode waters formation where significant air-sea heat and freshwater fluxes take place [e.g., Bryden and Imawaki, 2001; Wijffels, 2001]. The water mass census in this area reveals the influence of major intermediate, deep

Copyright 2004 by the American Geophysical Union. 0148-0227/04/2003JC002015 and bottom waters whose sources are far in the Antarctic and closer in the Nordic Seas, the Labrador and Mediterranean basins.

[3] The reviews by Schmitz and McCartney [1993] and Schmitz [1996] summarize and integrate the results from a variety of independent investigations with regard to the basin-wide circulation pattern in the North Atlantic. Other authors have derived the circulation at specific areas or across specific transoceanic sections directly from hydrographic measurements [e.g., Bacon, 1997; Bersch, 1995; Pollard et al., 1996; van Aken and Becker, 1996] or indirectly from inverse models [e.g., Cunningham, 2000; Martel and Wunsch, 1993; Mazé et al., 1997; Paillet and Mercier, 1997]. 


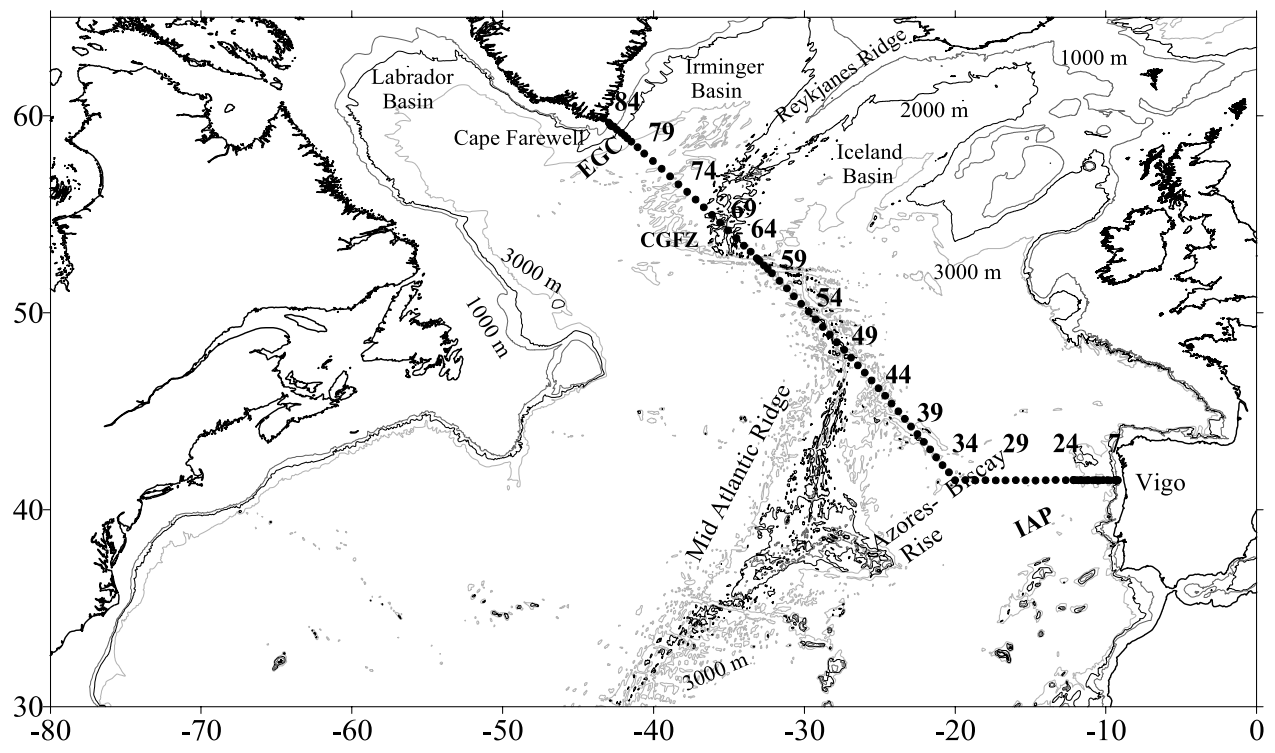

Figure 1. Station locations along the Vigo-Cape Farewell, WOCE A25, 4x section. EGC, East Greenland Current; IAP, Iberian Abyssal Plain; and CGFZ, Charlie-Gibbs Fracture Zone.

[4] Although a comprehensive picture of the water mass circulation in the subpolar North Atlantic is emerging some imbalances still remain. McCartney [1992] reported an excess of deep water production in the eastern North Atlantic which is presumably mixed or recirculated in this basin [Dickson and Brown, 1994]. Saunders [1994] reported a long-term mean transport of $2.4 \pm 0.5 \mathrm{~Sv}$ for deep waters across the Charlie-Gibbs Fracture Zone. This estimation is much less than the deep water production in the eastern North Atlantic basin (7.4 Sv) according to Dickson and Brown [1994]. On the other hand recent findings about a new formation site in the Irminger Sea for Labrador Seawater [Pickart et al., 2003] would be integrated in the classical global circulation patterns.

[5] In this work we thoroughly analyze the mass flux across a transoceanic World Ocean Circulation Experiment (WOCE) section in the subpolar North Atlantic gyre, WOCE A25 or 4x section, with the aim of giving insights about the regional and vertical structure of the mass transport in the subpolar North Atlantic within the context of the global thermohaline circulation proposed by Schmitz and McCartney [1993] and Schmitz [1996]. Furthermore, we combined the circulation pattern across the $4 \mathrm{x}$ section with the water mass structure obtained from a mixing analysis, so as to provide the relative contribution of each water mass to the transport of both physical (mass, heat, and freshwater) and biogeochemical (nutrients, oxygen, alkalinity, total inorganic carbon, and anthropogenic carbon) properties across the subpolar North Atlantic gyre.

\section{Data Set}

[6] As part of WOCE, a section was sampled in the subpolar North Atlantic Ocean from Vigo (northwestern Iberian Peninsula) to Cape Farewell (south Greenland) during the RRS Discovery cruise 230, 4x cruise, WOCE A25 line, in August-September 1997 (Figure 1).
[7] Continuous recording of temperature, salinity and pressure was obtained by a conductivity-temperature-depth (CTD) Neil Brown MKIII incorporated into a rosette sampler with 24 Niskin bottles. Subsamples for salinity, nutrients, oxygen, $\mathrm{pH}$ and alkalinity were taken during the cruise. Here we will briefly describe the methodologies employed for each variable analysis. A more detailed description about sampling procedures, measurement protocols, and data quality control checks is given by Bacon [1998].

[8] Hereafter, theta or $\theta$ will refer to potential temperature and $\mathrm{S}$ to salinity. Salinity samples were analyzed on a Guildline 8400A salinometer calibrated IAPSO Standard Seawater following the WOCE standards. Nutrients were analyzed on board using SOC Chemlab AAII type autoanalyzer coupled to a digital analysis microstream data capture and reduction system. Precision for nitrate $\left(\mathrm{NO}_{3}\right)$, phosphate $\left(\mathrm{PO}_{4}\right)$, and silicate $\left(\mathrm{SiO}_{4}\right)$ was evaluated at \pm 0.2 , \pm 0.05 , and $\pm 0.1 \mu \mathrm{mol} \mathrm{kg}{ }^{-1}$, respectively. Oxygen $\left(\mathrm{O}_{2}\right)$ was determined by Winkler potentiometric titration following the indications described in the WOCE Manual of Operations [Culberson, 1991]. Oxygen precision was better than $1 \mu \mathrm{mol} \mathrm{kg}{ }^{-1}$.

[9] Seawater $\mathrm{pH}$ was measured using a double wavelength spectrophotometric procedure [Clayton and Byrne, 1993]. The indicator was a $1 \mathrm{mM}$ solution of m-cresol purple sodium salt in Milli-Q water. All absorbance measurements were made by a Beckman DU600 spectrophotometer in a thermostat $10-\mathrm{cm}$ cell. Temperature was controlled using a refrigerated circulating temperature bath, all measurements were performed at $25^{\circ} \mathrm{C}$. Here $\mathrm{pH}$ was expressed on the total scale, and $\mathrm{pH}$ measurements were made to an accuracy of \pm 0.002 on the basis of analysis of certified reference material (CRM) provided by Dr. Dickson (Scripps Institution of Oceanography). Total alkalinity (TA) was determined by automatic potentiometric titration with $\mathrm{HCl}$ to a final pH of 4.44 [Pérez and Fraga, 1987]. The electrode was standardized using an NBS buffer of $\mathrm{pH}$ 7.413 and checked using an NBS buffer of 4.008. This 
method has a precision of $0.1 \%$ [Pérez and Fraga, 1987] and an accuracy of $\pm 2 \mu \mathrm{mol} \mathrm{kg}{ }^{-1}$ based on analysis of CRM.

[10] Total inorganic carbon (TIC) was estimated from $\mathrm{pH}$ and TA data using the thermodynamic equations of the carbonate system [Dickson, 1981] and the constants determined by Mehrbach et al. [1973]. This procedure was verified by Ríos and Rosón [1996] and the TIC error is estimated in $\pm 3 \mu \mathrm{mol} \mathrm{kg} \mathrm{kg}^{-1}$ according to error transmission.

[11] In this work, we use the approximation for calculating anthropogenic carbon $\left(\mathrm{C}_{\mathrm{ANT}}\right)$ suggested by Pérez et al. [2002] on the basis of an improved modification of the back-calculation technique proposed by Brewer [1978] and Chen and Millero [1979], further modified by Gruber et al. [1996]. The estimated error of $\mathrm{C}_{\mathrm{ANT}}$ is $7.4 \mu \mathrm{mol} \mathrm{kg}{ }^{-1}$, similar to the values proposed by Gruber et al. [1996], Körtzinger et al. [1998], or Sabine et al. [1999]. However, the average $\mathrm{C}_{\mathrm{ANT}}$ content for waters deeper than $4000 \mathrm{dbar}$ is $5.2 \pm 4 \mu \mathrm{mol} \mathrm{kg}{ }^{-1}$, indicating that the previous error estimate must express the maximum random variability; the averaging effect acting on independent errors decreases the random errors considerably.

\section{Determination of the Velocity Field and Transports}

[12] In this section we give an overview of the methodology followed by Álvarez et al. [2002] to obtain the geostrophic velocity field and the corresponding geostrophic transport of any physical or biogeochemical property across the $4 \mathrm{x}$ section.

[13] The geostrophic transport of any property across the $4 \mathrm{x}$ section can be computed as

$$
\mathrm{T}_{\text {Prop }}=\int_{\text {Vigo }}^{\text {Farewell }} \int_{-\mathrm{H}}^{0} \mathrm{v} \cdot \rho_{\mathrm{S}, \mathrm{T}, \mathrm{P}} \cdot \operatorname{Prop} \cdot \mathrm{dx} \cdot \mathrm{dz}
$$

where $T_{\text {Prop }}$ is the transport of any property, calculated by integrating the product of the property concentration (Prop), the velocity orthogonal to the section $(v)$ and the in situ density $\left(\rho_{\mathrm{S}, \mathrm{T}, \mathrm{P}}\right)$ from Vigo to Cape Farewell over the entire water column (that is, from the bottom, $-\mathrm{H}$, to the surface, $0)$. The triangular area remaining below the deepest common level at each pair of stations is treated separately: the transport in the bottom triangles is calculated by multiplying the velocity at deepest common level by the bottom triangle area and a weighted average of each property in the bottom triangle, including density. Throughout we use the convention that positive fluxes refer to northward transports orthogonal to the section.

[14] The velocity field is assumed to be geostrophically balanced except for the wind-driven Ekman layer. For calculating the geostrophic velocity with the thermal wind equation, CTD data recorded every 2 dbar for theta, salinity and pressure are smoothed to 20 dbar intervals for each station. Chemical data obtained at bottle depths were linearly interpolated to 20 dbar intervals, so as to match the physical fields. We make the assumption that the property distributions below the upper 100-200 dbar are uninfluenced by the seasonal cycle and represent long-term distributions in order to obtain a climatological estimate of the transports from a single section. $\mathrm{C}_{\mathrm{ANT}}$ values above
130 dbar were homogenized so as to avoid biases due to biological activity [Álvarez et al., 2003].

[15] The determination of the velocity field is thoroughly described by Alvarez et al. [2002], here we will present just an overview of the process. The circulation pattern is initially approximated in order to reproduce the closest to reality estimate of the velocity field. This is our "initial guess" which is finally introduced into an inverse model with additional constraints so as to obtain the "best estimate" of the circulation. Careful attention was paid in the definition of the "initial guess" as the inverse model results will depend on it [Rintoul and Wunsch, 1991]. The geostrophic velocity was initially calculated referenced for a fixed level of no motion (LNM) equal to $3200 \mathrm{dbar}$ [Saunders, 1982]. Then, the LNM was changed to $\sigma_{2}=$ $36.94 \mathrm{~kg} \mathrm{~m}^{-3}$ everywhere except in the Iberian Abyssal Plain. The mass imbalance obtained after this adjustment is compensated by a uniform barotropic velocity distributed across the section. On the basis of direct observations and reliable estimations of the mass transport at specific areas crossed by the section we proceeded to adjust the mass flux at three locations: the Iberian Abyssal Plain (IAP), the Charlie-Gibbs Fracture Zone (CGFZ) and the western boundary region within $110 \mathrm{~km}$ off Greenland, in the East Greenland Current (EGC). Specifically, the mass transport was adjusted to zero below about $2000 \mathrm{dbar}$ in the IAP, to $-2.4 \mathrm{~Sv}\left(1 \mathrm{~Sv}=10^{6} \mathrm{~m}^{3} \mathrm{~s}^{-1}\right)$ southward in the CGFZ for waters with $\sigma_{\theta}>27.8 \mathrm{~kg} \mathrm{~m}^{-3}$ [Saunders, 1994] and to $-25 \mathrm{~Sv}$ southward for the whole water column in the EGC [Bacon, 1997]. After these considerations the salt transport was adjusted to zero as we assume the North Atlantic Ocean north of the $4 \mathrm{x}$ section to be a closed basin. We assume that the net flow between Greenland and Europe must be small $(0 \pm 1 \mathrm{~Sv})$ and disregard it [Álvarez et al., 2002]. After this final adjustment the "initial guess" circulation is obtained. A high silicate flux $\left(-105 \mathrm{kmol} \mathrm{s}^{-1}\right)$ was obtained with the former pattern of circulation. Consequently, an inverse model was set to force the silicate transport to the riverine input of silicate north of the section, $\left(26 \mathrm{kmol} \mathrm{s}^{-1}\right.$, estimated from the recent review of the silica cycle by Tréguer et al. [1995]), along with conserving salt and minimizing the total net mass flux. Minor barotropic corrections were calculated with the inverse model, after their application over the "initial guess" circulation its "best estimate" is obtained.

\section{Mixing Analysis}

[16] The water mass structure along the $4 \mathrm{x}$ section is resolved by means of an extended optimum multiparameter (OMP) approach [Karstensen and Tomczak, 1998; Poole and Tomczak, 1999]. Briefly, the OMP method consists on quantifying the mixture of a set of source water types (SWT) that makes up a given water parcel/sample. The mixing is solved by minimizing the residuals of a set of tracer linear mixing equations for conservative and nonconservative variables in a nonnegative least squares (NNLS) sense, where mass is stringently conserved and the contributions of the different SWT must be positive.

[17] In this analysis we have used as conservative parameters theta, salinity and assumed the conservative behavior of silicate. The nonconservative tracers used were nitrate, 
Table 1. Characteristics, Errors and Weights (W) of the SWT Matrix ${ }^{a}$

\begin{tabular}{|c|c|c|c|c|c|c|}
\hline SWT & $\Theta,{ }^{\circ} \mathrm{C}$ & Salinity, psu & $\mathrm{NO}_{3}, \mu \mathrm{mol} \mathrm{kg}{ }^{-1}$ & $\mathrm{PO}_{4}, \mu \mathrm{mol} \mathrm{kg}{ }^{-1}$ & $\mathrm{O}_{2}, \mu \mathrm{mol} \mathrm{kg}^{-1}$ & $\mathrm{SiO}_{4}, \mu \mathrm{mol} \mathrm{kg}{ }^{-1}$ \\
\hline $\mathrm{ENACW}_{\mathrm{T}}$ & $15.30 \pm 0.13$ & $36.12 \pm 0.017$ & $0.02 \pm 0.4$ & $0.03 \pm 0.10$ & $228 . \pm 2$ & $0.2 \pm 0.5$ \\
\hline $\mathrm{H}$ & $12.20 \pm 0.13$ & $35.66 \pm 0.017$ & $7.1 \pm 0.4$ & $0.42 \pm 0.10$ & $262 \pm 2$ & $3.4 \pm 0.5$ \\
\hline ENACW $_{P}$ & $8.00 \pm 0.10$ & $35.23 \pm 0.017$ & $9.6 \pm 0.2$ & $0.71 \pm 0.05$ & $286 \pm 5$ & $11.2 \pm 1$ \\
\hline SAIW & $5.60 \pm 0.10$ & $34.70 \pm 0.017$ & $12.9 \pm 0.4$ & $0.98 \pm 0.05$ & $309 \pm 2$ & $5.9 \pm 1$ \\
\hline AA & $7.90 \pm 0.10$ & $35.00 \pm 0.017$ & $11.1 \pm 0.4$ & $0.95 \pm 0.10$ & $281 \pm 2$ & $13.1 \pm 1$ \\
\hline $\mathrm{EGC}_{\mathrm{T}}$ & $3.70 \pm 0.10$ & $34.78 \pm 0.017$ & $21.2 \pm 0.4$ & $1.47 \pm 0.10$ & $286 \pm 2$ & $7.3 \pm 1$ \\
\hline MW & $11.74 \pm 0.10$ & $36.50 \pm 0.017$ & $7.1 \pm 0.4$ & $0.36 \pm 0.05$ & $263 \pm 2$ & $8.6 \pm 1$ \\
\hline LSW & $2.90 \pm 0.15$ & $34.84 \pm 0.017$ & $13.5 \pm 0.4$ & $0.99 \pm 0.02$ & $323 \pm 3$ & $10.3 \pm 1$ \\
\hline ISOW & $1.93 \pm 0.10$ & $34.96 \pm 0.010$ & $10.5 \pm 0.4$ & $0.87 \pm 0.05$ & $329 \pm 1$ & $10.9 \pm 1$ \\
\hline DSOW & $1.20 \pm 0.10$ & $34.89 \pm 0.017$ & $11.2 \pm 0.3$ & $0.91 \pm 0.05$ & $339 \pm 1$ & $9.3 \pm 1$ \\
\hline LDW & $2.03 \pm 0.01$ & $34.89 \pm 0.003$ & $13.7 \pm 0.4$ & $1.01 \pm 0.02$ & $331 \pm 1$ & $47.5 \pm 0.4$ \\
\hline W & 10 & 9 & 3 & 1 & 3 & 4 \\
\hline$r^{2}$ & 1.0000 & 0.9999 & 0.9972 & 0.9709 & 0.9846 & 0.9988 \\
\hline Std. Err. & 0.02 & 0.003 & 0.2 & 0.05 & 4 & 0.3 \\
\hline
\end{tabular}

${ }^{\mathrm{a}}$ Correlation coefficient $\left(\mathrm{r}^{2}\right)$ and standard error (Std. Err.) of the regression between the measured and modeled variable. Number of data is 1529 . ENACW, Eastern North Atlantic Central Water subtropical and subpolar; SAIW, SubArctic Intermediate Water; AA, influenced Antarctic Intermediate Water; $\mathrm{EGC}_{\mathrm{T}}$, East Greenland Current type; MW, Mediterranean Water; LSW, Labrador Seawater; ISOW, Iceland-Scotland Overflow Water; DSOW, Denmark Strait Overflow Water; and LDW, Lower Deep Water.

phosphate and oxygen. Biological processes are modeled using oxygen, so that oxygen consumption from the initial close to saturation conditions is converted to nitrate and phosphate units using the Redfield ratios by Anderson and Sarmiento [1994].

\subsection{Source Characterization}

\subsubsection{Upper Waters}

[18] The upper $1000 \mathrm{dbar}$ in the North Atlantic are the domain of mode waters which are those formed by deep winter convection driven by heat loss at the sea surface [McCartney and Talley, 1982]. The term subpolar Mode Water comprises one of the largest volumes of mode waters in the North Atlantic Ocean with temperatures ranging from 3 to $14^{\circ} \mathrm{C}$. Pycnostads of this water sandwiched between the main pycnocline and the seasonal pycnocline circulate within the North Atlantic basins giving rise to different varieties. In this study we will refer to the Eastern North Atlantic Central Water (ENACW) variety [Harvey, 1982; Ríos et al., 1992; Pollard et al., 1996]. Within ENACW two varieties can be discerned [Fiúza, 1984; Ríos et al., 1992], colder subpolar ENACW moving southward west of Galicia (NW Spain) and warmer subtropical ENACW moving northward between the Azores and Portugal. Subpolar ENACW forms east of $20^{\circ} \mathrm{W}$ and north of $42^{\circ} \mathrm{N}$ with temperatures less than $12.2^{\circ} \mathrm{C}$ [Fraga et al., 1982; Harvey, 1982; Fiúza, 1984; Pollard et al., 1996]. Subtropical ENACW is characterized by higher temperatures $\left(>13^{\circ} \mathrm{C}\right)$ and formed in the area of the Azores Current [Pollard and Pu, 1985; Rios et al., 1992].

[19] As an upper limit for subtropical ENACW (designed as ENACW $\mathrm{T}_{\mathrm{T}}$ ) we choose the $\theta-\mathrm{S}$ values of $15.3^{\circ} \mathrm{C}$ and 36.12 in agreement with Ríos et al. [1992] and Castro et al. [1998], for its lower limit the $\theta-\mathrm{S}$ values of $12.2^{\circ} \mathrm{C}$ and 35.66 , which is the upper limit of ENACW defined by Harvey [1982] and coincides with that proposed by Pollard and $P u$ [1985]. In our analysis this end-member is designed as $\mathrm{H}$ in honor of Harvey. The lower limit of subpolar ENACW is designed as ENACW $\mathrm{P}_{\mathrm{P}}$ and defined with the $\theta-\mathrm{S}$ values of $8^{\circ} \mathrm{C}$ and 35.23 , as proposed by van Aken and de Boer [1995] in agreement with McCartney and Talley [1982] and Castro et al. [1998]. See Table 1.
[20] Subarctic Intermediate Water (SAIW) with $\theta$ from 4 to $7^{\circ} \mathrm{C}$ and $\mathrm{S}$ less than 34.9 [Bubnov, 1968] is not a mode water formed by thermal convection [Arhan, 1990]. SAIW originates in the western boundary of the subpolar gyre [Wüst, 1978; Iselin, 1936; Bubnov, 1968; Read and Ellett, 1991], by mixing of warm saline water from the North Atlantic Current (NAC) with cold low-salinity water from the Labrador Current. Southward from the line of vanishing Ekman suction SAIW subducts into the permanent thermocline and spreads southward [Arhan, 1990; Read and Ellett, 1991] northwest of the Azores Plateau [Worthington, 1976], but it was also found as far east as $20^{\circ} \mathrm{W}$ by Harvey [1982]. In this study SAIW is defined with the following $\theta-S$ characteristics $5.6^{\circ} \mathrm{C}$ and 34.7 (Table 1), lying within the "pure" SAIW domain defined by Harvey and Arhan [1988].

[21] A sharp shallow front in temperature and salinity between stations 59 and 64 over the CGFZ (Figures 2a and $2 \mathrm{~b}$ ) identifies the northern branch of the NAC turning eastward [Iselin, 1936; Worthington, 1976; McCartney and Talley, 1982; Sy, 1988; Arhan, 1990]. This front separates colder and less saline waters northward from warmer and saltier water southward. The signal of SAIW is clearly seen in the upper $500 \mathrm{dbar}$ north of the NAC in a core of water with salinity and temperature less than 34.9 and $5^{\circ} \mathrm{C}$, respectively and a relative silicate maximum of about $11 \mu \mathrm{mol} \mathrm{kg} \mathrm{kg}^{-1}$ (Figure 2).

[22] Antarctic Intermediate Water (AAIW) is formed at the Subantarctic front at about $45^{\circ} \mathrm{S}$ by ventilation of Subantarctic Mode Water formed in the southeast Pacific [McCartney, 1977, 1982; Reid, 1994]. The AAIW spreading along the South Atlantic until about $20^{\circ} \mathrm{N}$ is clearly detected as a salinity minimum at $\sigma_{\theta}=27-27.3 \mathrm{~kg} \mathrm{~m}^{-3}$ [Wüst, 1978; Reid, 1989; Suga and Talley, 1995]. However, north of $20^{\circ} \mathrm{N}$, AAIW can also be detected by its high and contrasting silicate content [Metcalf, 1969; Mann et al., 1973; Tsuchiya, 1989]. Using silicate Tsuchiya [1989] traced the extension of AAIW in the North Atlantic transported by the Gulf Stream-North Atlantic Current. In this study we refer to the diluted AAIW encountered in the North Atlantic as AA with the $\theta-\mathrm{S}$ characteristics of $7.9^{\circ} \mathrm{C}$ and 35 in agreement with former studies at $20^{\circ} \mathrm{N}$ [Fraga et al., 1985; Tsuchiya et al., 1992; Pérez et al., 2001]. 

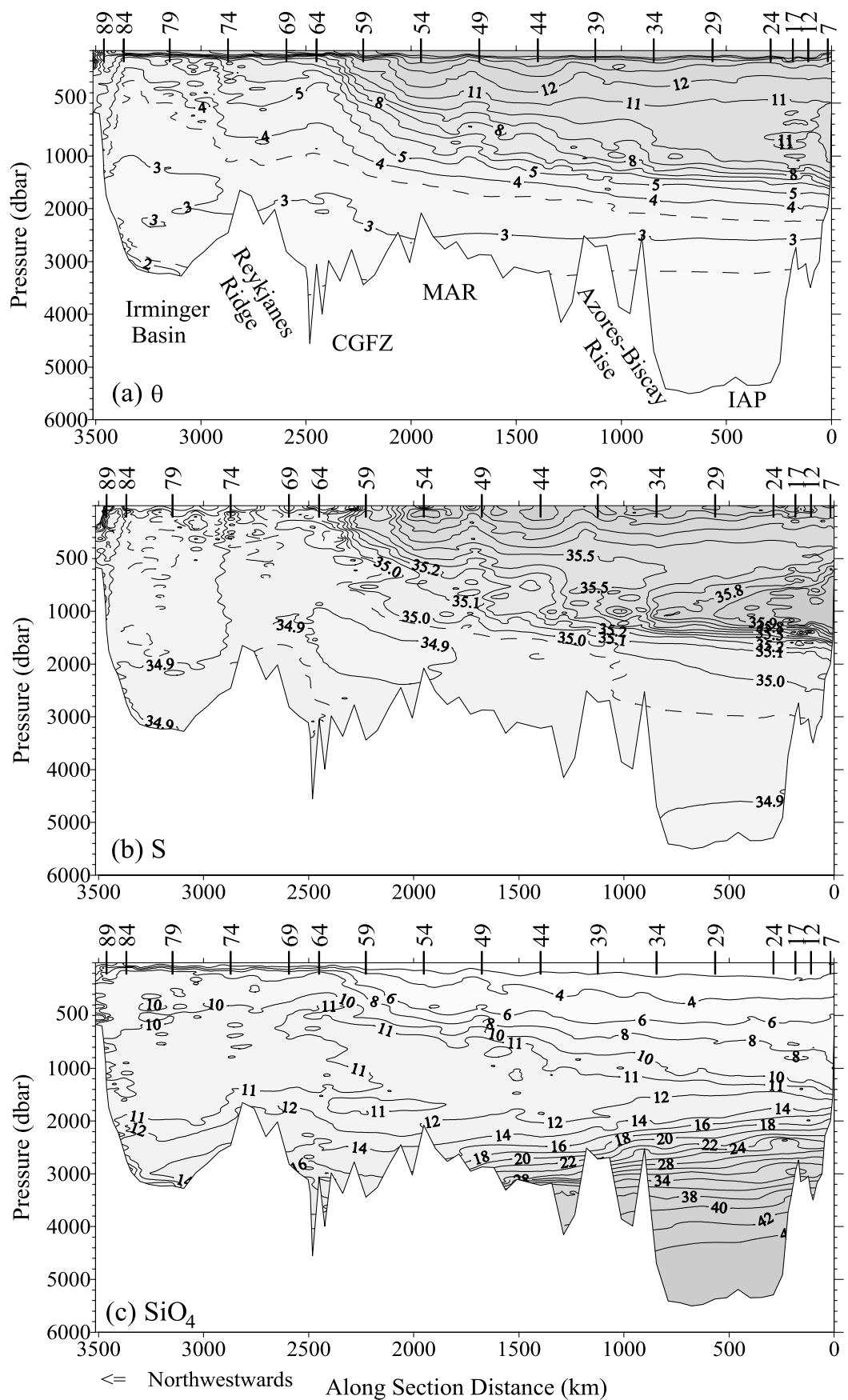

Figure 2. Vertical distributions along the $4 \mathrm{x}$ section of (a) potential temperature $\left(\theta\right.$ in $\left.{ }^{\circ} \mathrm{C}\right)$, (b) salinity ( $\mathrm{S}$ in psu), and (c) silicate $\left(\mathrm{SiO}_{4}\right.$ in $\left.\mu \mathrm{mol} \mathrm{kg}{ }^{-1}\right)$. Note the different scale for the upper $1000 \mathrm{dbar}$. Isolines for $3.5^{\circ}$ and $2.5^{\circ} \mathrm{C}$ and for 34.95 and 34.85 psu were added to Figures $2 \mathrm{a}$ and $2 \mathrm{~b}$, respectively. CGFZ, Charlie-Gibbs Fracture Zone; MAR, Mid-Atlantic Ridge; and IAP, Iberian Abyssal Plain.

[23] From station 84 shoreward there is a weak thermal and haline front in the upper $700 \mathrm{dbar}$ (Figure 2) because of the presence of a cold and fresh water mass probably with an Arctic origin which we call East Greenland Current Type $\left(\mathrm{EGC}_{\mathrm{T}}\right)$ and define in Table 1 , with $3.69^{\circ} \mathrm{C}$ and 34.78 .

\subsubsection{Intermediate Waters}

[24] This subsection deals with waters situated in the 1000 to 2000 dbar range in the North Atlantic. Centered upon 1000 dbar a salinity maximum traces the Mediterranean Water (MW) core in the eastern North Atlantic, also characterized by a temperature maximum (Figures 2a and $2 \mathrm{~b}$ ). For the MW end-member we choose $11.74^{\circ} \mathrm{C}$ and 36.5, which are the thermohaline MW representative characteristics after it has sunk and stabilized at about 1000 meters depth in the Atlantic Ocean [Zenk, 1975; Wüst and Defant, 1936; Ambar and Howe, 1979].

[25] Labrador Seawater (LSW) can be traced as a potential vorticity minimum with temperatures of approximately $3.4^{\circ} \mathrm{C}$, about 34.89 of salinity and high oxygen content [Talley and McCartney, 1982; Harvey and Arhan, 1988; 
Tsuchiya et al., 1992; Arhan et al., 1994; Cunningham and Haine, 1995]. The classical circulation pattern of LSW in the North Atlantic was described by Talley and McCartney [1982]. From the Labrador Sea the newly formed LSW is advected in three main directions: northeastward into the Irminger Sea, southeastward across the Atlantic at about $50^{\circ} \mathrm{N}$ into the eastern basin, and southward with the Labrador Current. Just one source region located in the Labrador Sea was taken into account to depict this pattern. However, a new one should be emerging if deep convection occurs in the Irminger Sea, being a second source for LSW [Pickart et al., 2003].

[26] Pickart et al. [2003] showed a time series of the temperature and salinity in the LSW core in the Labrador and Irminger Seas, reporting the low theta $\left(<3^{\circ} \mathrm{C}\right)$ and fresh salinity $(<34.86 \mathrm{psu})$ of LSW in both basins during the $95 \mathrm{~s}$. In this work we select the $\theta-\mathrm{S}$ characteristics of $2.9^{\circ} \mathrm{C}$ and 34.84 for LSW as also reported by Bersch [1995], Stoll et al. [1996] and Sy et al. [1997].

[27] LSW is clearly detected in the thermohaline and chemical vertical distributions along the section with a $\theta$ and $\mathrm{S}$ minimum (Figures $2 \mathrm{a}$ and $2 \mathrm{~b}$ ). In the Irminger Basin LSW is detected as an homogeneous thermohaline layer centered at 2000 dbar. From the Labrador Sea LSW spreads into the eastern basin at shallower depths where its $\theta$ and $\mathrm{S}$ minima are eroded by the overlaying MW with $\theta$ and $\mathrm{S}$ maxima (Figures $2 \mathrm{a}$ and $2 \mathrm{~b}$ ).

\subsubsection{Deep and Bottom Waters}

[28] Lower Deep Water (LDW) is warmed Antarctic Bottom Water entering the eastern North Atlantic at the Vema Fracture, from here it spreads north initially against the western margin to about $30^{\circ} \mathrm{N}$ and then against the eastern margin of the eastern basin [Saunders, 1987; McCartney et al., 1991]. North of $30^{\circ} \mathrm{N}$ LDW flows northward as an eastern intensified flow [Saunders, 1987] proceeding to the Rockall Trough and Plateau [Mann et al., 1973; McCartney, 1992; Tsuchiya et al., 1992; Dickson and Brown, 1994] and then westward to the Iceland basin toward the CGFZ, where it joins the deep Iceland Scotland Overflow (ISOW). Continuing northward as a deep northern boundary current to the Irminger Sea and finally joining the Deep Western Boundary Current, a portion of LDW is proposed to recirculate southward in the eastern basin [McCartney, 1992; Dickson and Brown, 1994]. Lee and Ellett [1967] defined North Eastern Atlantic Deep Water (NEADW) as the deep water underlying the LSW core south of the Rockall Plateau. In the Iberian Basin down from 2500 dbar NEADW is quite homogeneous in its thermohaline characteristics (Figures 2a and $2 \mathrm{~b}$ ) with a linear trend in the $\theta-\mathrm{S}$ representation [Saunders, 1986; Mantyla, 1994], silicate concentrations higher than $24 \mu \mathrm{mol} \mathrm{kg} \mathrm{kg}^{-1}$ (Figure 2c). Silicate presents a steep vertical gradient pointing to the influence of water originating from the Southern Ocean in NEADW [Tsuchiya et al., 1992; Arhan et al., 1994]. For LDW in the Iberian Basin we select the $\theta-\mathrm{S}$ values given by Castro et al. [1998] (Table 1).

[29] The overflows spilling over the Greenland-Scotland ridge system into the deep North Atlantic basins constitute a major source of salt to the deep water of the world ocean [Reid and Lynn, 1971; Swift, 1984]. The Denmark Strait Overflow Water (DSOW) is a well-ventilated young overflow water passing through the Denmark Strait [Swift et al.,
1980; Swift, 1984]. The formation area of DSOW was proposed to be the Greenland Sea where it forms by isopycnal mixing within the East Greenland Current [Strass et al., 1993]. However, in a recent work, Mauritzen [1996] proposed that the more likely source for DSOW is the Arctic Ocean where the Arctic Atlantic Water forms and flows with the East Greenland Current toward the Denmark Strait.

[30] Within the Denmark Strait the DSOW is characterized by salinities from 34.8 to $34.9, \theta$ from 0 to $1^{\circ} \mathrm{C}$ and $\sigma_{\theta}$ from 27.95 to $28 \mathrm{~kg} \mathrm{~m}^{-3}$ [Swift et al., 1980; Swift, 1984]. After leaving the Denmark Strait DSOW descends and mixes with Atlantic Water carried west by the Irminger Current and its $\theta-\mathrm{S}$ characteristics are modified, becoming warmer [Mann, 1969]. Our selected values for the $\theta-S$ properties of the DSOW type were taken from Stoll et al. [1996], obtained in the Irminger Sea, near Cape Farewell. See Table 1. Temperatures below $2^{\circ} \mathrm{C}$ (Figure 2a) in the Irminger Sea indicate the presence of DSOW.

[31] Norwegian Sea Overflow Water (NSOW) flows into the Iceland Basin across the sills in the Faroe Bank Channel and in the Iceland-Faroe Ridge, NSOW and Arctic Intermediate Water entrain surface subpolar water [Dooly and Meincke, 1981; van Aken and Eisma, 1987] and form a new more or less homogeneous water type, Iceland Scotland Overflow Water, ISOW [Ellett and Martin, 1973; Harvey and Theodorou, 1986, ISOW1]. Following the latter authors we choose the ISOW's $\theta-\mathrm{S}$ characteristics to be $1.93^{\circ} \mathrm{C}$ and 34.96 , very similar to those reported by van Aken and de Boer [1995] and Stoll et al. [1996] in the Iceland Sea. The ISOW influence is detected above DSOW in the Irminger Sea and at the bottom of the CGFZ with temperatures less than $3^{\circ} \mathrm{C}$ and salinity in the range between 35.95 and 35 (Figures $2 \mathrm{a}$ and $2 \mathrm{~b}$ ). A recent work by Fleischmann et al. [2001] evidence the transport of ISOW from the Iceland basin to the West European basin, however it is only clearly detected with the distributions of transient tracers as Freons or tritium.

[32] The tracer values for the different SWT are listed in Table 1. Thermohaline characteristics are taken from the literature as commented previously. Silicate values for each SWT are first extrapolated from $\mathrm{S}_{-} \mathrm{SiO}_{4}$ regression lines. After obtaining the contribution matrix, a type vector for $\mathrm{SiO}_{4}$ is calculated. The former $\mathrm{SiO}_{4}$ values are reintroduced as initial characteristics and the model is solved again. This iterative process is repeated until the difference between introduced and modeled $\mathrm{SiO}_{4}$ values is at a minimum. Nitrate, phosphate and oxygen characteristics represent preformed values, see that oxygen values are close to saturation and nutrient values are low. The same iterative process is applied to these tracers. Each tracer has an estimation error obtained as by Poole and Tomczak [1999].

[33] Within the OMP analysis each tracer equation is properly weighted, each weight is calculated dividing the standard deviation of the tracer in the SWT matrix and the sum of the analytical error plus the maximum error ascribed to the estimation of the SWT tracers (Table 1). A weight of 100 has been attributed to the mass conservation equation, thus is always accurately conserved.

\subsection{Mixing Constraints}

[34] The total number of unknowns is twelve, eleven SWT contributions and the biological activity introduced 
(a) South of the NAC

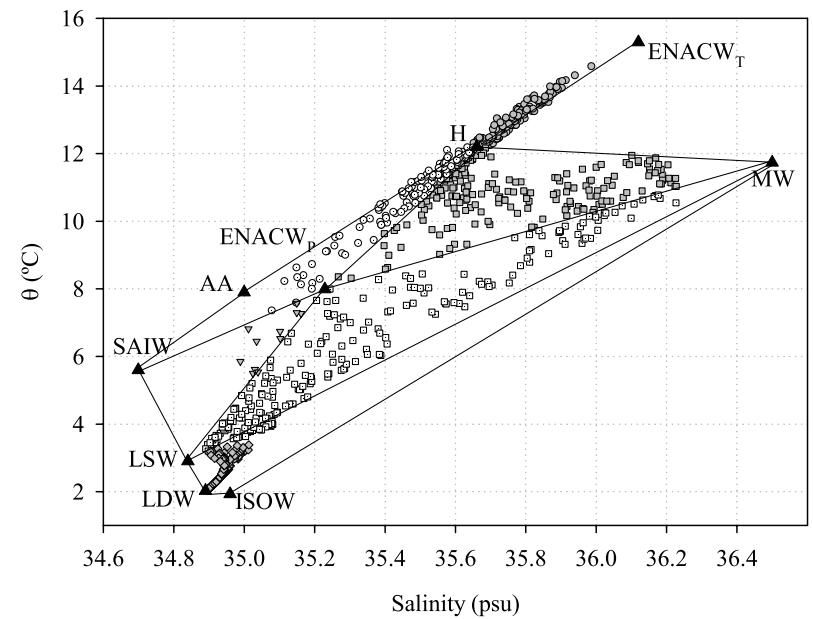

(b) North of the NAC

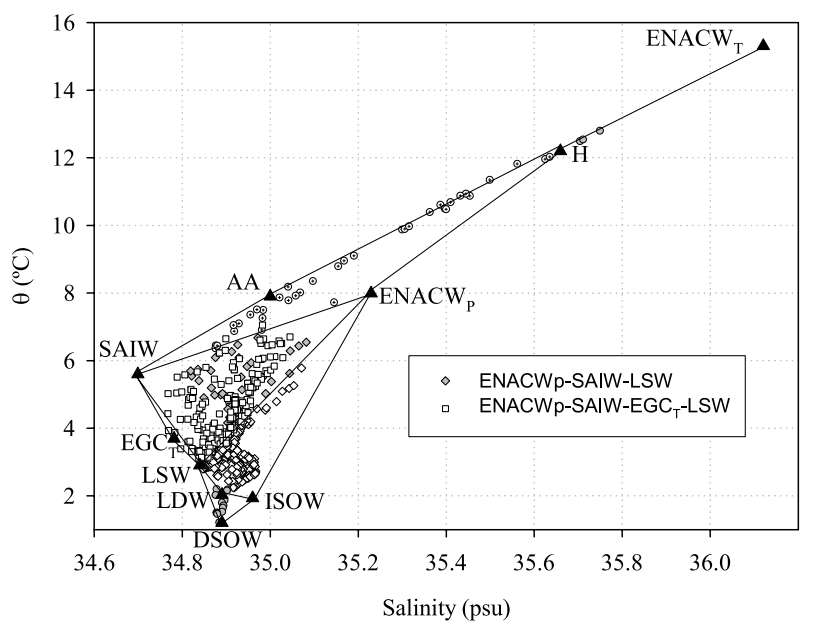

Figure 3. Potential $\theta-\mathrm{S}$ diagrams for bottle samples collected during the $4 \mathrm{x}$ cruise: (a) south of the North Atlantic Current (NAC) and (b) north of the NAC. Characteristics of the source water types are also represented. Samples belonging to surface waters are not included.

as a function of oxygen. On the other hand the number of tracers used in the mixing analysis is six (Table 1). Therefore only a maximum of six SWT can be simultaneously considered. In order to solve this problem we propose several oceanographic constraints or criteria for water mass mixing. First, samples are separated according to the oceanographic frontal area situated at the NAC (Figure 2). North of the NAC no MW is allowed in the mixing model. South of the NAC, MW mixes with $\mathrm{H}$ and $\mathrm{ENACW}_{\mathrm{P}}$ in agreement with previous works [Pérez et al., 1993; Castro et al., 1998], other mixing spaces south of the NAC are H-AA-

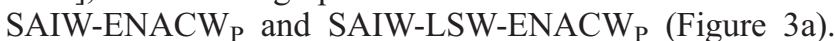
Thus AA is not allowed to mix with LSW. Intermediate waters are resolved by the following mixing space, LSWMW-ENACW

[35] Figures $2 \mathrm{a}$ and $2 \mathrm{~b}$ show that waters below $2000 \mathrm{dbar}$ are very homogeneous in their physical features, but silicate presents an eastward increasing trend (Figure 2c). There- fore, although the water flowing northward against the eastern margin has the same $\theta-\mathrm{S}$ characteristics as that flowing southward against the eastern flank of the MAR, its silicate content is lower. In this sense, the most likely low-silicate source water for the northeastern Atlantic basin with similar $\theta$-S features as LDW is ISOW. So, the space defined by LDW-LSW-ISOW-MW is used to solve the mixing of deep waters south of the NAC (Figure 3a).

[36] Mixing spaces north of the NAC are represented in Figure $3 \mathrm{~b}$. North of the NAC and south of the Reykjanes Ridge the upper waters mixing is solved by the $\mathrm{ENACW}_{\mathrm{T}} \mathrm{H}$ line and the H-SAIW-AA-ENACW P $_{P}$ space and SAIWENACW $W_{\mathrm{P}}-\mathrm{LSW}$. Within the Irminger Sea the mixing of upper waters is resolved using $\mathrm{SAIW}-\mathrm{EGC}_{\mathrm{T}}-\mathrm{ENACW}_{\mathrm{P}^{-}}$ LSW.

[37] As previously introduced, LDW-influenced water (NEADW) in the Iceland, Irminger Seas and the CGFZ was reported by several authors [Mann et al., 1973; Tsuchiya et al., 1992; van Aken and Becker, 1996]. Therefore, to resolve the mixing dynamics of deep and bottom waters, we propose the quadrangles defined by LDW-LSWISOW-ENACW $_{P}$ and LDW-LSW-ISOW-DSOW, respectively (Figure 3b).

[38] This mixing spaces will be proved to be representative and reliable along the section, and thus in the subpolar North Atlantic as will be contrasted in the following section.

[39] Some samples were not comprised within the former mixing spaces and therefore not resolved by the mixing model. These samples correspond to the seasonal thermocline, being affected by seasonal warming and/or ice melting, and must be discarded in an OMP analysis, which assumes stationary state in the SWT characteristics.

\subsection{Reliability and Robustness of the Mixing Model}

[40] The residuals produced when solving the OMP equations and the ability of the model to reproduce the measured values of the tracers introduced give insights about the reliability of the proposed mixing model.

[41] The NNLS method returns the squared largest singular value for the set of residuals resulted from the whole set of linear equations (total residual). The total residual for the individual samples is shown in Figure 4a and the relative dimensionless and weighted contribution from each equation $\left(\theta, \mathrm{S}, \mathrm{NO}_{3}, \mathrm{PO}_{4}, \mathrm{SiO}_{4}\right.$, and mass conservation) is shown in Figures $4 \mathrm{~b}$ and 4 c. $92 \%$ of the samples present a total residual value less than 0.15 (Figure 4a). Samples with a poorer fit are concentrated in the upper $1000 \mathrm{dbar}$ because of their higher thermohaline and chemical variability (Figures $4 \mathrm{~b}$ and $4 \mathrm{c}$ ). Below 1000 dbar the uncertainty of the model is due to the nitrate, phosphate and oxygen variability as the model reproduces very well the thermohaline and silicate distribution (Figures $4 \mathrm{~b}$ and $4 \mathrm{c}$ ).

[42] The correlation coefficient $\left(\mathrm{r}^{2}\right)$ between the measured and expected values for the introduced tracers and the standard error (Std.Err.) of the corresponding residuals provide an estimation of the goodness of our proposed mixing model. In the case of the tracers introduced in the model the $\mathrm{r}^{2}$ values are higher than 0.97 , and the corresponding Std. Err. of the residuals keep low, $0.02^{\circ} \mathrm{C}$, $0.003,0.2,0.05,4$, and $0.3 \mu \mathrm{mol} \mathrm{kg}{ }^{-1}$, for theta, salinity, nitrate, phosphate, oxygen, and silicate, respectively, slightly higher than the corresponding measurement error (Table 1). 

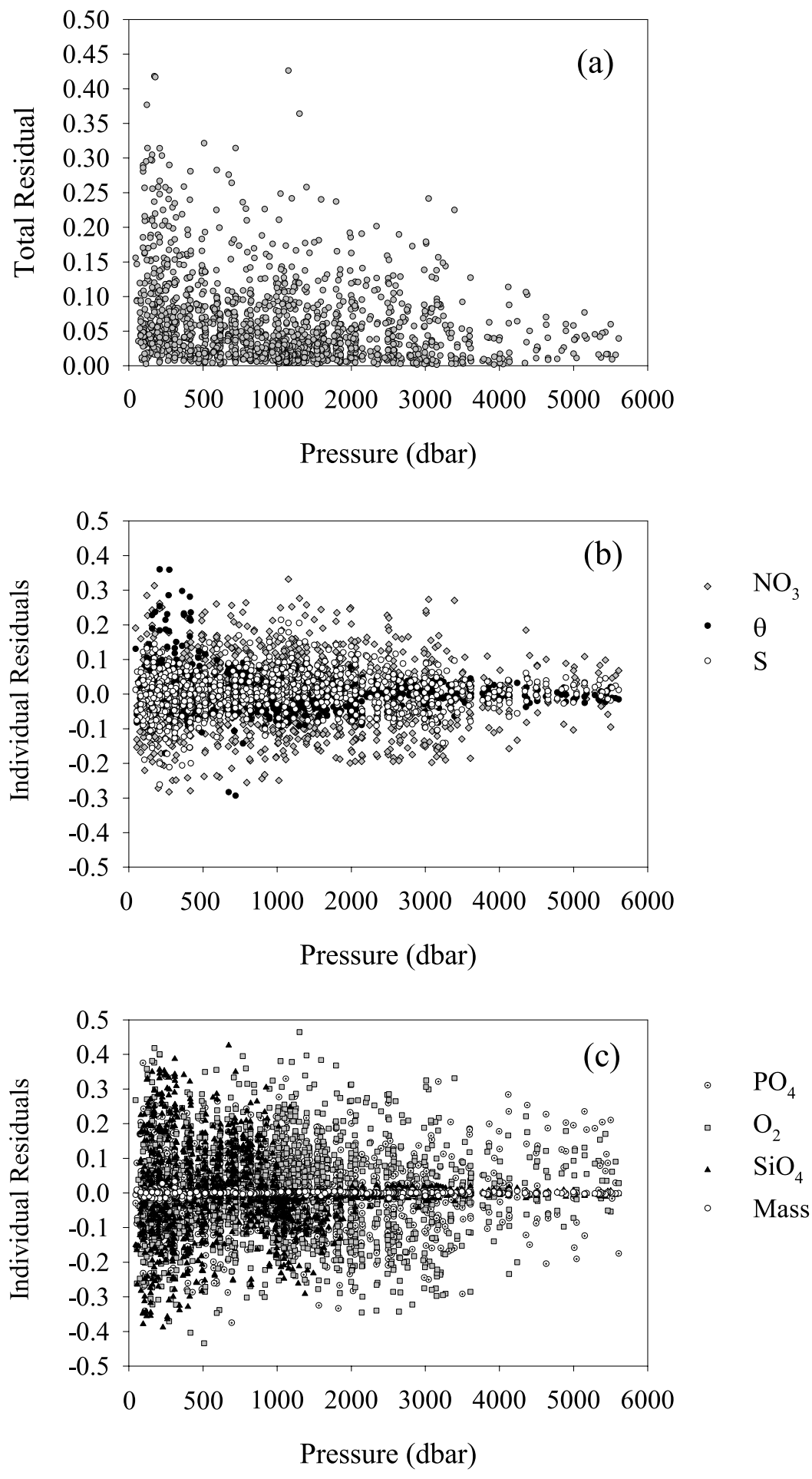

Figure 4. (a) Total residuals from the mixing model and individual dimensionless and weighted residuals from each equation introduced in the mixing analysis; (b) potential temperature, salinity, and nitrate and (c) phosphate, oxygen, silicate, and mass conservation. Note the wider scale for the upper 1000 dbar.

The former results point to the reliability of the mixing model, able to reproduce with a high degree of confidence the thermohaline and chemical variability along the section.

[43] The robustness or stability of the model is tested by numerical perturbation experiments. The SWT matrix is modified in the following manner: normally distributed random numbers are multiplied by the error assigned to each tracer and SWT (Table 1), these numbers are then added to the SWT matrix, to finally resolve the system. A total of 100 perturbations are computed to then calculate the mean and standard deviation (STD) of the solution matrix. This STD gives an estimation of the system stability. Table 2 
Table 2. Mean and Standard Deviation (STD) of the Standard Deviation Values Obtained for Each SWT Contribution After the Perturbation Analysis

\begin{tabular}{lcc}
\hline \multicolumn{1}{c}{ SWT } & Mean, $\%$ & STD, $\%$ \\
\hline ENACW $_{\mathrm{T}}$ & 0.7 & 0.1 \\
H & 0.8 & 0.2 \\
ENACWP & 1.0 & 0.7 \\
SAIW & 1.3 & 0.6 \\
AA & 2.4 & 1.0 \\
EGC & 2.3 & 1.1 \\
MW & 0.4 & 0.2 \\
LSW & 1.8 & 0.9 \\
ISOW & 2.1 & 0.9 \\
DSOW & 2.5 & 0.6 \\
LDW & 0.6 & 0.2 \\
\hline
\end{tabular}

indicates the mean values of the former STD values. The mixing model is stable as these mean STD values are low, the SWT with higher mean STD values are those with less samples in the figures defined with them, AA, $\mathrm{EGC}_{\mathrm{T}}$, DSOW and ISOW (Table 2).

\subsection{SWT Contributions}

[44] The mean SWT contributions along the 4x section are shown in Figure 5. ENACW mode waters: ENACW $\mathrm{T}_{-} \mathrm{H}$ and $\mathrm{H}-\mathrm{ENACW} \mathrm{P}_{\mathrm{P}}$, respectively. For the sake of simplicity these three SWT contributions have been summed and represented in Figure 5a. The maximum contribution of $\mathrm{H}$ represents the lower limit of subtropical ENACW, which predominates in the upper $300 \mathrm{dbar}$ of the eastern end of the $4 \mathrm{x}$ section, south of the NAC. The NAC structure is marked as an abrupt gradient in the ENACW isolines between station 59 and 64, over the CGFZ (Figure 5a).

[45] The maximum of $\mathrm{H}$ (line in Figure 5a) marks the transition from subtropical (upward) to subpolar (downward) ENACW. Higher contributions of subpolar ENACW are situated below the subtropical variety at 600-900 dbar east of the MAR, smaller contributions of subpolar ENACW are found shallower west of the MAR (Figure 5a).

[46] East of the MAR, modified Antarctic Intermediate Water (the AA type; Figure 5c) freshens subpolar ENACW. AA was found around $600 \mathrm{dbar}$ in the same geographical location as ENACW and reaching about station $42\left(44.2^{\circ} \mathrm{N}\right.$, $\left.23^{\circ} \mathrm{W}\right)$. AA reached a maximum contribution of only $40 \%$ within the NAC, constituting only a $10 \%$ of pure AAIW as encountered at the Subantarctic Front with $3.9^{\circ} \mathrm{C}$ and 34.2.

[47] The fresher and colder SAIW was mainly found in the upper $500 \mathrm{dbar}$ north of the NAC, subducting south of it and spreading southeastward at about 500 dbar (Figure 5b), where it mixes laterally with subpolar ENACW and vertically with the underlying LSW. The SAIW signal is lost around station $54\left(28.3^{\circ} \mathrm{W}-48.9^{\circ} \mathrm{N}\right)$. In the Irminger Sea, minor contributions of subpolar ENACW were found in the
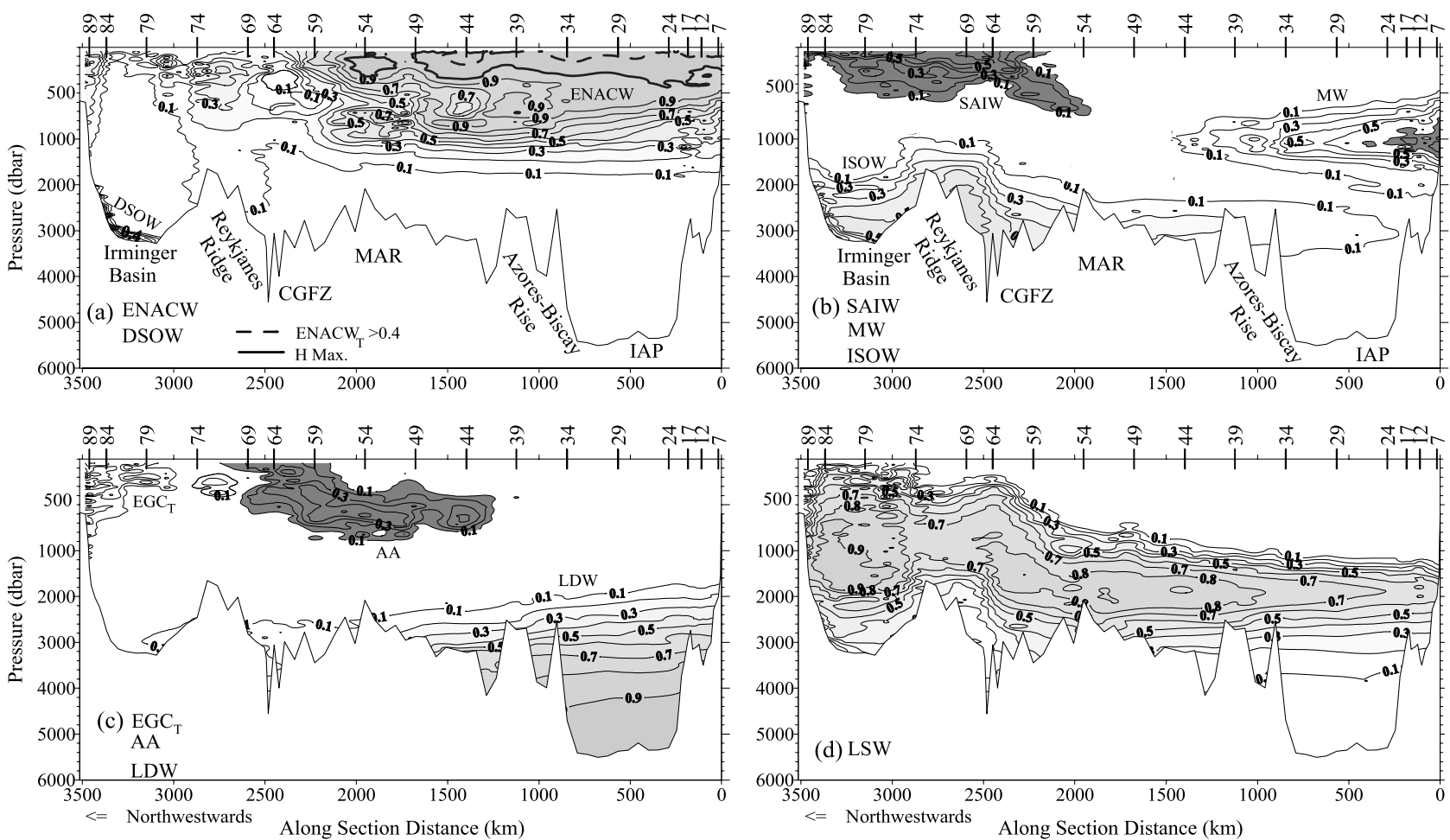

Figure 5. Source water types mean contribution along the $4 x$ section, vertically ordered: (a) Eastern North Atlantic Central Water (ENACW) and Denmark Strait Overflow Water (DSOW), (b) Subarctic Intermediate Water (SAIW), Mediterranean Water (MW) and Iceland Scotland Overflow Water (ISOW), (c) East Greenland Current type $\left(\mathrm{EGC}_{\mathrm{T}}\right)$, modified Antarctic Intermediate Water (AA) and Lower Deep Water (LDW), and (d) Labrador Seawater (LSW). Note the different scale for the upper 1000 dbar. CGFZ, Charlie-Gibbs Fracture Zone; MAR, Mid-Atlantic Ridge; and IAP, Iberian Abyssal Plain. 
upper 1000 dbar (Figure 5a), in this region predominates the fresher and colder SAIW (Figure 5b) and the densest mode of subpolar mode water, LSW (Figure 5d).

[48] The MW core was found about 1100 dbar being eroded in its westward spreading by turbulent mixing [Mazé et al., 1997; Arhan and King, 1995] by subpolar ENACW (Figure 5b).

[49] Three main cores of LSW can be distinguished in Figure 5d: the northernmost, a doming core in the Irminger Sea, either coming directly from the Labrador Sea, formed there or both; a core situated over the CGFZ which corresponds to the Talley and McCartney's [1982] "eastern branch" and finally, a core corresponding to the southwestward recirculation of LSW between $42^{\circ}-50^{\circ} \mathrm{N}$ situated from the MAR to the Azores Biscay Rise. Eastward from this topographic ridge LSW is rapidly diluted with the overlying MW (Figure 5b) [Arhan et al., 1994; Tsuchiya et al., 1992; Paillet et al., 1998] giving rise to the saltier Deep Mediterranean Water by a rapid mixing process. Figure $5 \mathrm{~d}$ confirms that LSW reaches the North Atlantic eastern boundary in relatively high proportions as first mentioned by Pingree [1973].

[50] LDW constitutes the major water mass below 3200 dbar in the Iberian Basin (Figure 5c), while from 2000 to $3200 \mathrm{dbar}$ it mixes with LSW, eroding the NEADW salinity maximum signal [Tsuchiya et al., 1992; Arhan et al., 1994]. Note the sloping trend of the isolines of LDW toward the eastern margin (Figure 5c), confirming the eastward intensification of the northward flow of LDW and deep upwelling along the European coast [Stommel and Arons, 1960; Arhan et al., 1994]. Toward the MAR, LDW is diluted with LSW and minor proportions of ISOW, which is also found in the bottom layer against the eastern MAR (Figure 5b) confirming the results by Fleischmann et al. [2001]. Both ISOW and LSW contribute to reduce the silicate content of deep waters in the eastern flank of the MAR. ISOW once crossed over the CGFZ proceeds northward into the Irminger Sea where it encounters on its upper part LSW and on its lower part DSOW, especially in the western slope of the Irminger Sea (Figure 5).

[51] In the CGFZ, LSW mixes with the underlying ISOW crossing to the western basin preferentially along the CGFZ northern wall (Figure 5b) [Swift, 1984; Harvey and Theodorou, 1986]. Minor contributions of LDW were found in this region (Figure 5c), evidencing the flow of Antarcticinfluenced water from the eastern to the western Atlantic. Low but significant fractions of LDW were even found against the eastern flank of the Irminger basin.

\section{Transports by Temperature Classes}

[52] Transports for physical and biogeochemical tracers are integrated according to $\theta$ classes, which correspond to $1^{\circ} \mathrm{C}$ intervals from 1.5 to $21.5^{\circ} \mathrm{C}$ (Figure 6). The Ekman transport is incorporated in the corresponding $\theta$ class. Thus the full depth integral of these values yields the net transport across the $4 \mathrm{x}$ section.

[53] Briefly, the vertical distribution of $\theta$ along the $4 x$ section (Figure 2a) shows that the main physical feature crossed by the $4 \mathrm{x}$ section is the North Atlantic Current (NAC) discerned as a $\theta$ frontal area in the upper $1000 \mathrm{dbar}$ over the CGFZ, separating colder and fresher waters northward from warmer and saltier waters southward. Below 1000 dbar isotherms are practically parallel, except for the localized influence of the colder DSOW and ISOW over the western flank of the Irminger Sea and the CGFZ, respectively.

[54] Waters with $\theta$ higher than $15^{\circ} \mathrm{C}$ correspond to the seasonal thermocline affected by seasonal warming, the classes from 15 to $8^{\circ} \mathrm{C}$ mainly comprise the mode waters, subpolar and subtropical, ENACW and MW; from 8 to $5^{\circ} \mathrm{C}$ is the domain of SAIW and AA; LSW is mainly found in the 4.5 to $2.5^{\circ} \mathrm{C}$ classes. The deep water LDW and the two overflows ISOW and DSOW occupy the $\theta<2.5^{\circ} \mathrm{C}$ classes.

[55] The mass transport by $\theta$ classes presents a two-lobe structure (Figure 6a), with positive or northeastward (NE hereafter) transport for $\theta>6.5^{\circ} \mathrm{C}$ classes and negative or southwestward (SW hereafter) transport for colder classes. Warmer than $6.5^{\circ} \mathrm{C}$ waters transport $21.2 \mathrm{~Sv}$ and colder waters $-21.6 \mathrm{~Sv}$. The total mass transport across the $4 \mathrm{x}$ section amounts to $-0.4 \mathrm{~Sv}$ and correspond to net precipitation plus runoff over evaporation over the basin north of the 4x section [Álvarez et al., 2002].

[56] The strongest NE mass transport is concentrated in the $10.5^{\circ}-11.5^{\circ} \mathrm{C}$ class, which mainly corresponds to subpolar ENACW. Most of the northward transport of warm waters occurs within the NAC region, south of station 64 . Whereas the main SW flow of up to $-15.7 \mathrm{~Sv}$ is located in the $2.5^{\circ}-3.5^{\circ} \mathrm{C}$ class mainly related with LSW.

[57] According to Schmitz [1996] a circulation scheme with more than $14 \mathrm{~Sv}$ of upper warm water $\left(\theta>7^{\circ} \mathrm{C}\right)$ moving from the subtropics into the subpolar area needs to return the excess relative to $14 \mathrm{~Sv}$ of this water south in the upper layer or provide more than $14 \mathrm{~Sv}$ of lower water $(\theta<$ $7^{\circ} \mathrm{C}$ ) formed or joined to form North Atlantic Deep Water. Our results point to a northward circulation of warm waters mainly within the NAC area which are then cooled down preferentially in the Greenland-Iceland-Norwegian Seas to form the deep overflows or the densest mode of Subpolar Mode Water with characteristics very similar to Labrador Seawater, mix to depth and return southward preferentially within the East Greenland Current.

[58] The transports into $\theta$ classes of other physical (heat and salt) and biogeochemical (nutrients, $\mathrm{O}_{2}, \mathrm{TA}, \mathrm{TIC}$, and $\mathrm{C}_{\mathrm{ANT}}$ ) properties resemble the mass transport (Figure 6). This is a consequence of the correlation between the $\theta, \mathrm{S}$ and chemical fields. Additionally, this result points to the relevance of determining a reliable velocity field when calculating transports across transoceanic sections. A net flux of mass SW does not necessarily lead to a transport of any other property in the same direction. For example, the coldest $\theta$ class presents a SW mass flow, as well as other property transports except $\mathrm{SiO}_{4}$ (Figure 6f). In the case of $\mathrm{SiO}_{4}$, water with $\theta<2.5^{\circ} \mathrm{C}$ in the IAP flowing $\mathrm{NE}$ has a much higher $\mathrm{SiO}_{4}$ concentration than the overflows in the Irminger Basin and CGFZ flowing SW. Thus the $\mathrm{NE} \mathrm{SiO}_{4}$ transport greatly exceeds the SW one because of the contrasting $\mathrm{SiO}_{4}$ concentration at the $1.5^{\circ}-2.5^{\circ} \mathrm{C}$ class (see Figures $2 \mathrm{a}$ and $2 \mathrm{c}$ ).

[59] See Álvarez et al. [2002, 2003] for a wide discussion about the mechanisms leading to the transports across the $4 \mathrm{x}$ section. In summary, nutrients, oxygen and TIC present a net SW transport across the section. The overturning cell is the main mechanism responsible for the SW transport of 

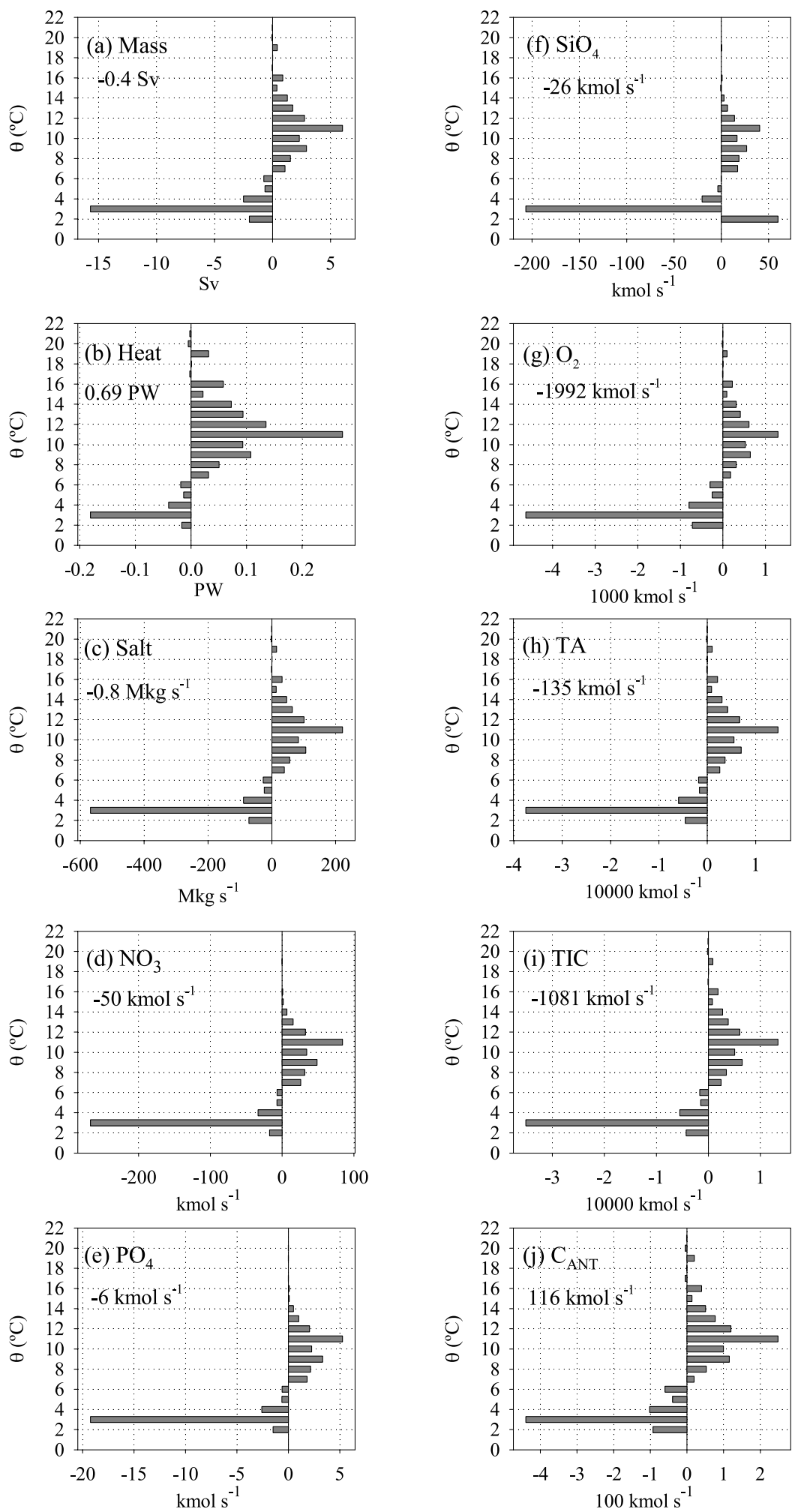

Figure 6. Transport into $\theta$ classes across the $4 \mathrm{x}$ section for (a) mass, (b) heat, (c) salt, (d) nitrate $\left(\mathrm{NO}_{3}\right)$, (e) phosphate $\left(\mathrm{PO}_{4}\right)$, (f) silicate $\left(\mathrm{SiO}_{4}\right),(\mathrm{g})$ oxygen $\left(\mathrm{O}_{2}\right)$, (h) total alkalinity (TA), (i) total inorganic carbon (TIC), and (j) anthropogenic carbon $\left(\mathrm{C}_{\mathrm{ANT}}\right)$. Units are $\mathrm{Sv}\left(1 \mathrm{~Sv}=10^{6} \mathrm{~m}^{3} \mathrm{~s}^{-1}\right), \mathrm{PW}\left(10^{15} \mathrm{~W}\right), \mathrm{Mkg} \mathrm{s}^{-1}$ $\left(10^{6} \mathrm{~kg} \mathrm{~s}^{-1}\right)$, and $\mathrm{kmol} \mathrm{s}^{-1}\left(1000 \mathrm{~mol} \mathrm{~s}^{-1}\right)$. In the corresponding subplot is also shown the total net transport across the $4 \mathrm{x}$ section of each property. Positive values indicate northeastward transport. 


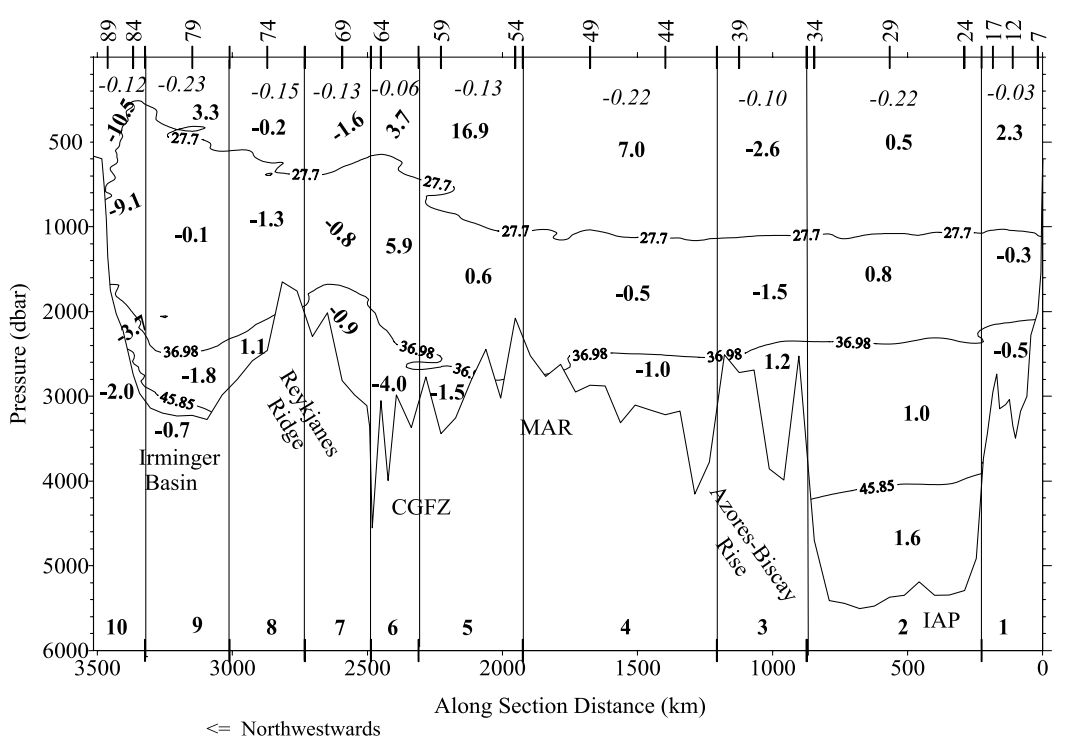

Figure 7. Regional and vertical distribution of the mass transport across the $4 \mathrm{x}$ section. Negative values indicate southward or southwestward transports. $1 \mathrm{~Sv}=10^{6} \mathrm{~m}^{3} \mathrm{~s}^{-1}$. Density layers are from the surface to $\sigma_{\theta}<27.7 \mathrm{~kg} \mathrm{~m}^{-3}, \sigma_{\theta} \geq 27.7$ to $\sigma_{2} \leq 36.98 \mathrm{~kg} \mathrm{~m}^{-3}, \sigma_{2}>36.98$ to $\sigma_{4}<45.85 \mathrm{~kg} \mathrm{~m}^{-3}$, and $\sigma_{4} \geq$ $45.85 \mathrm{~kg} \mathrm{~m}^{-3}$ denominated as upper, intermediate, deep, and bottom, respectively. IAP, Iberian Abyssal Plain; CGFZ, Charlie-Gibbs Fracture Zone; and MAR, Mid-Atlantic Ridge.

nutrients, whereas oxygen is mainly transported in the horizontal circulation cell and TIC because of the net mass barotropic SW transport across the section. In the case of salt and TA their transport is practically negligible, as constrained. The only properties transported NE are heat and $\mathrm{C}_{\mathrm{ANT}}$ with a relevant contribution from the overturning cell.

[60] Figure 6 shows that nutrients, oxygen, and TIC are transported SW because of the higher contribution from the coldest $\theta$ classes, this is because in general these properties increase with decreasing theta. Whereas heat and $\mathrm{C}_{\mathrm{ANT}}$ present a decreasing profile with theta and the contribution from the warmest classes exceeds that from the coldest. Concretely, warm waters carry $0.96 \mathrm{PW}$ and $849 \mathrm{kmol} \mathrm{s}^{-1}$ and cold waters $-0.27 \mathrm{PW}$ and $-733 \mathrm{kmol} \mathrm{s}^{-1}$ of heat and $\mathrm{C}_{\mathrm{ANT}}$, respectively.

[61] The $2.5^{\circ}-3.5^{\circ} \mathrm{C}$ class or LSW domain stands out with a strong SW mass flow that combined with the high oxygen and nutrient concentration in this layer yields extremely high SW oxygen and nutrient transports (Figures 6d-6g).

\section{Transports by Density Intervals}

[62] In order to more clearly describe the mass transport across the $4 \mathrm{x}$ section, the section has been divided into 10 geographical regions mainly according to bathymetric features and the water column into 4 density layers, which are ultimately related with the distribution of water masses (Figure 7). Therefore, from top to bottom, the upper layer comprises from the surface to $\sigma_{\theta}<27.7 \mathrm{~kg} \mathrm{~m}^{-3}$ and represents the central waters domain, mainly comprising ENACW, SAIW and AA. The intermediate layer comprises from $\sigma_{\theta} \geq 27.7$ to $\sigma_{2}<36.98 \mathrm{~kg} \mathrm{~m}^{-3}$, being the LSW domain. MW is comprised within the upper and intermediate layers. The deep layer, from $\sigma_{2} \geq 36.98$ to $\sigma_{4}<45.85 \mathrm{~kg} \mathrm{~m}^{-3}$, comprises deep waters in the IAP and bottom waters on both sides of the MAR (Figure 7). The bottom layer comprises waters denser than $\sigma_{4}=45.85 \mathrm{~kg} \mathrm{~m}^{-3}$ and is mainly associated with the DSOW in the Irminger Basin and LDW in the IAP.

[63] Figure 7 shows the regional and vertical distribution of the volume fluxes across the section. The Ekman transport is shown separately in the upper layer. A total of $17.4 \mathrm{~Sv}$ flow in the upper layer, $-6.5 \mathrm{~Sv}$ in the intermediate, $-10.2 \mathrm{~Sv}$ in the deep and only $-1.1 \mathrm{~Sv}$ in the bottom layer.

[64] A northward flow of $2.1 \mathrm{~Sv}$ was obtained in the Iberian Basin for waters denser than $\sigma_{2}=36.98 \mathrm{~kg} \mathrm{~m}^{-3}$, this flow in the context of global circulation corresponds to the $2 \mathrm{~Sv}$ of modified Antarctic Bottom Water [Schmitz and McCartney, 1993; Schmitz, 1996] flowing northward across the Iberian Basin to join the northern overflows. Saunders [1982] proposed a weak northward transport across $41.5^{\circ} \mathrm{N}$ at intermediate depth levels as calculated in this work, whereas in the upper 1000 dbar we obtained 2.25 Sv flowing northward mainly concentrated over the continental slope, in disagreement with Saunders [1982], who calculated $-2.5 \mathrm{~Sv}$ flowing southward across $41.5^{\circ} \mathrm{N}$.

[65] The NAC system transports 27.2 Sv NE across the section from the Azores-Biscay Rise to the CGFZ, 21.4 Sv are ascribed to waters warmer than $7^{\circ} \mathrm{C}$. These figures compare favorably with those proposed by Maillard [1984], Fahrbach et al. [1985], Krauss [1986], and Sy et al. [1992] or the recent review by Rossby [1996]. However, Schmitz [1996] gives only $12 \mathrm{~Sv}$ of warm water $\left(\theta>7^{\circ} \mathrm{C}\right)$ to flow within the NAC. Near the Azores-Biscay Rise -2.6 Sv are flowing SW in the upper layer as part of the recirculation of the NAC system and probably feeding the Azores Current [Paillet and Mercier, 1997].

[66] At the LSW level south of the CGFZ the inferred circulation pattern agrees with that proposed by several authors [Talley and McCartney, 1982; Arhan et al., 1989; 
Paillet et al., 1998], with a NE transport on the western side of the MAR and SW on the eastern side. Concretely, $6.5 \mathrm{~Sv}$ cross over the MAR at about $35^{\circ} \mathrm{W}$ (about $2300 \mathrm{~km}$ from Vigo), of which $-2.0 \mathrm{~Sv}$ recirculate southward on the eastern flank. These figures compare strikingly well with those proposed by Paillet and Mercier [1997] from an inverse model. However, they contradict the $13 \mathrm{~Sv}$ of warm waters $\left(\theta>7^{\circ} \mathrm{C}\right)$ crossing the MAR proposed by McCartney [1992] or Schmitz and McCartney [1993], here we just obtained $7 \mathrm{~Sv}$.

[67] At regions 5, 6 and 7 (western flank of the MAR and CGFZ) $-6.4 \mathrm{~Sv}$ of deep water flow to the western basin and ultimately join the DWBC. This figure compares well with the circulation pattern proposed by Schmitz and McCartney [1993] and reviewed by Schmitz [1996] (6-7 Sv), and also with a recent calculation in the area by Bacon [1997] (5 Sv). Although weak, there is a net SW deep flow of $-1 \mathrm{~Sv}$ over the eastern flank of the MAR, corresponding to ISOWinfluenced water recirculated into the eastern basin [Bacon, 1997; Fleischmann et al., 2001].

[68] The upper layer in region 7 on the eastern flank of the Reykjanes Ridge transports $-1.6 \mathrm{~Sv}$ southwestward, while in the western flank (region $8,55.4^{\circ} \mathrm{N}-36.7^{\circ} \mathrm{W}$ ) the upper layer only transports $-0.2 \mathrm{~Sv}$ as it comprises a cyclonic eddy of about $3 \mathrm{~Sv}$. The former region is usually associated with the northward Irminger current, estimated as $9 \mathrm{~Sv}$ at $59^{\circ} \mathrm{N}$ and $9.6 \mathrm{~Sv}$ at $62^{\circ} \mathrm{N}$ by Bacon [1997] and Krauss [1995], respectively. Therefore it seems that the Irminger current is not crossed by the $4 \mathrm{x}$ section and probably bends from the Iceland to the Irminger sea further north.

[69] In the Irminger basin (regions 8, 9, and 10), about $-18 \mathrm{~Sv}$ of water below $4^{\circ} \mathrm{C}$ are transported SW, likewise, $-6.8 \mathrm{~Sv}$ of warmer water are also carried in that direction. Schmitz and McCartney [1993] proposed -16 Sv and $-14 \mathrm{~Sv}$ of water colder and warmer, respectively, than $4^{\circ} \mathrm{C}$. McCartney [1992] and Dickson and Brown [1994] proposed $-2.9 \mathrm{~Sv}$ of DSOW to be produced in the Denmark Strait. At the densest layer of the Irminger Sea (regions 9 and 10) we obtained a flow of $-2.7 \mathrm{~Sv}$ (Figure 7). Within the EGC $-15.5 \mathrm{~Sv}$ of water colder than $4^{\circ} \mathrm{C}$ are transported SW which compare with the $-15 \mathrm{~Sv}$ or the $-16 \mathrm{~Sv}$ of $1.8^{\circ}-4^{\circ} \mathrm{C}$ water proposed by Schmitz and McCartney [1993] and Schmitz [1996], respectively. About $400 \mathrm{~km}$ off Cape Farewell, Dickson and Brown [1994], on the basis of a 1978 currentmeter data set from R. A. Clarke report a transport of $-13.3 \mathrm{~Sv} \mathrm{SW}$ for waters at $\sigma_{\theta} \geq 27.8 \mathrm{~kg} \mathrm{~m}^{-3}$. Across the $4 \mathrm{x}$ section we obtained $-6.2 \mathrm{~Sv}$. This mismatch can be attributed to the short period of the moorings' deployment (60 days) or/and to the recirculating Labrador Seawater included in their estimation or to the uncertainty in our results.

[70] Similar pictures as Figure 7 can be derived for any other physical or biogeochemical property. However, for the sake of space the regional and vertical distribution of these transports is represented in a more simplistic manner in Figure 8. This figure shows the regional (regions as in Figure 7) transport by density intervals (intervals as in Figure 7) accumulated from Vigo (right end) to Cape Farewell (left end) for the different properties. Figure 8a is just a different representation of the results shown in Figure 7. As also concluded from Figure 6 the vertical and regional physical and biogeochemical transports resemble that of mass. The NAC (regions 4, 5, and 6) stands out as the main contributor to the NE mass transport in the upper layer, while the EGC (region 10) is the main contributor to the SW transport but affecting the whole water column (Figure 8a).

[71] Except for heat (Figure 8b) and $\mathrm{SiO}_{4}$ (Figure 8f) the regional vertical distribution of the other physico-biogeochemical transports shown in Figure 8 are practically analogous. The properties, except heat and $\mathrm{SiO}_{4}$, are mainly transported NE in the upper layer within the NAC system (regions 4, 5, and 6), which greatly exceeds the SW contribution from the EGC (region 10). The intermediate and deep layers present a final SW transport mainly due to the great contribution at the CGFZ (region 6) and the EGC (region 10), the transport at the bottom layer is practically negligible (Figure 8).

[72] The heat transport is overwhelmingly concentrated in the upper layer (Figure 8b) in comparison with the structure of the other transports. In the case of $\mathrm{SiO}_{4}$ (Figure 8f), the deep layer is the largest contributor to the total transport. The transport of $\mathrm{SiO}_{4}$ also presents a significant contribution from the bottom layer. Concretely, LDW with a high $\mathrm{SiO}_{4}$ content flows northward in the IAP (region 2; Figure 8f).

[73] $\mathrm{C}_{\mathrm{ANT}}$ is mainly transported $\mathrm{NE}$ in the upper layer at the NAC (Figure $8 \mathrm{j}$ ), note the significantly high $\mathrm{C}_{\mathrm{ANT}}$ transport SW in the EGC whole water column (region 10). The balance between net advection of $\mathrm{C}_{\mathrm{ANT}}$, the vertical mixing between upper young and deep old waters and the $\mathrm{C}_{\mathrm{ANT}}$ accumulation within the North Atlantic determines the air-sea $\mathrm{C}_{\mathrm{ANT}}$ flux [Holfort et al., 1998; Rosón et al., 2003; Völker et al., 2002; Alvarez et al., 2003]. The first two terms relate with the circulation pattern (overturning, vertical structure, etc.) and therefore with the warm-to-cold water conversion. Thus the relevance of assessing the magnitude of the heat flux in the North Atlantic from direct determinations, which will eventually help to constrain and reveal weaknesses in global ocean circulation models. Reconciling model results with direct estimates for heat and $\mathrm{C}_{\mathrm{ANT}}$ airsea fluxes and ocean transports is one of the remaining tasks to be currently resolved in oceanography (see Bryden and Imawaki [2001, and references therein] for heatrelated questions and Sarmiento et al. [2000, and references therein] and $\mathrm{Orr}$ et al. [2001, and references therein] for $\mathrm{C}_{\mathrm{ANT}}$ ).

\section{Transports by Water Masses}

[74] This subsection quantifies the relative contribution from each water mass (Table 3 ) to the different physical (mass, heat, and salt) and biogeochemical (nutrients, $\mathrm{O}_{2}$, TA, TIC, and $\mathrm{C}_{\mathrm{ANT}}$ ) tracer transports across the $4 \mathrm{x}$ section. As previously introduced, the results from a mixing analysis were combined with those regarding the physical and biogeochemical transports across the section (see Álvarez et al. [2002] for the mass, heat, salt, nutrients, and oxygen transports and Álvarez et al. [2003] for the TA, TIC, and $\mathrm{C}_{\mathrm{ANT}}$ results).

[75] In order to obtain the contribution of each water mass to the transports, the geostrophic transport field must be multiplied by the corresponding SWT contribution field. Therefore the SWT contributions obtained at bottle depths 

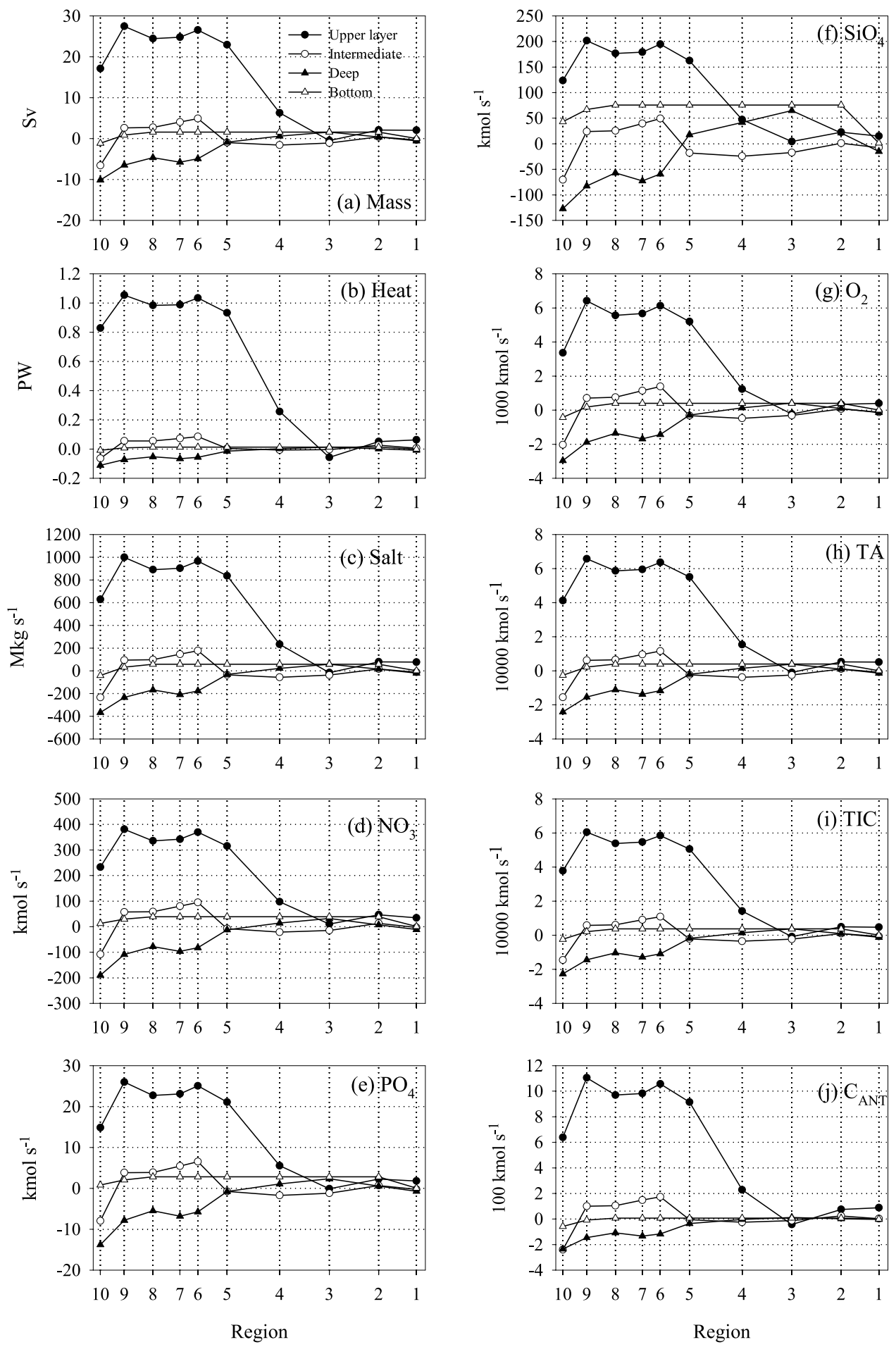

Figure 8. Regional and vertical net transports across the $4 \mathrm{x}$ section accumulated from Vigo (right end) for (a) mass, (b) heat, (c) salt, (d) nitrate $\left(\mathrm{NO}_{3}\right)$, (e) phosphate $\left(\mathrm{PO}_{4}\right)$, (f) silicate $\left(\mathrm{SiO}_{4}\right)$, (g) oxygen $\left(\mathrm{O}_{2}\right)$, (h) total alkalinity (TA), (i) total inorganic carbon (TIC), and (j) anthropogenic carbon ( $\mathrm{C}_{\mathrm{ANT}}$ ). Units are $\mathrm{Sv}\left(1 \mathrm{~Sv}=10^{6} \mathrm{~m}^{3} \mathrm{~s}^{-1}\right)$, PW $\left(10^{15} \mathrm{~W}\right), \mathrm{Mkg} \mathrm{s}^{-1}\left(10^{6} \mathrm{~kg} \mathrm{~s}^{-1}\right)$, and kmol s${ }^{-1}\left(1000 \mathrm{~mol} \mathrm{~s}^{-1}\right)$. Regions and density intervals are as in Figure 7.

were also linearly interpolated to 20 dbar intervals and averaged every pair of stations, so as to match the velocity field. The SWT contributions at the triangular area remaining below the deepest common level of each pair of stations are calculated from a weighted average of each SWT in the bottom triangle, in the same way as any other property, as described by Álvarez et al. [2002]. The property transports are calculated multiplying the geostrophic transport of each SWT times its mean property value in the section obtained as by Castro et al. [1998]. 
Table 3. Physical and Biogeochemical Transports Across the $4 x$ Section Accounted for by the Different Water Masses ${ }^{\mathrm{a}}$

\begin{tabular}{|c|c|c|c|c|c|c|c|c|c|c|}
\hline & $\begin{array}{c}\text { Mass, } \\
\text { Sv }\end{array}$ & $\begin{array}{c}\text { Heat, } \\
\text { PW }\end{array}$ & $\begin{array}{c}\text { Salt, } \\
\mathrm{Mkg} \mathrm{s}^{-1}\end{array}$ & $\begin{array}{l}\mathrm{NO}_{3}, \\
\mathrm{kmol} \mathrm{s}^{-1} \\
\end{array}$ & $\begin{array}{l}\text { PO4, } \\
\mathrm{kmol} \mathrm{s}^{-1}\end{array}$ & $\begin{array}{c}\mathrm{SiO}_{4}, \\
\mathrm{kmol} \mathrm{s}^{-1}\end{array}$ & $\begin{array}{c}\mathrm{O}_{2}, \\
\mathrm{kmol} \mathrm{s}^{-1}\end{array}$ & $\begin{array}{c}\text { TA, } \\
\text { kmol s }^{-1}\end{array}$ & $\begin{array}{c}\text { TIC, } \\
\text { kmol s }^{-1}\end{array}$ & $\begin{array}{c}\mathrm{C}_{\text {ANT }} \\
\mathrm{kmol} \mathrm{s}^{-1} \\
\end{array}$ \\
\hline ENACW & 10.3 & 0.60 & 381.0 & 79 & 4 & 28 & 2347 & 24894 & 22324 & 484 \\
\hline SAIW & 2.9 & 0.07 & 104.6 & 40 & 3 & 20 & 922 & 6863 & 6383 & 174 \\
\hline AA & 5.6 & 0.18 & 200.8 & 117 & 9 & 76 & 1044 & 13265 & 12463 & 159 \\
\hline $\mathrm{EGC}_{\mathrm{T}}$ & -3.5 & -0.05 & -124.2 & -54 & -4 & -21 & -1256 & -8231 & -7665 & -258 \\
\hline (EGC n.a.) & $(-1.9)$ & $(-0.04)$ & $(-67.5)$ & $(-18)$ & $(-2)$ & $(-11)$ & $(-614)$ & $(-4507)$ & $(-4167)$ & $(-66)$ \\
\hline MW & 1.7 & 0.08 & 62.5 & 27.3 & 1.6 & 15 & 289 & 4152 & 3800 & 48 \\
\hline LSW & -8.8 & -0.10 & -317.4 & -154 & -11 & -94 & -2623 & -20915 & -19603 & -274 \\
\hline ISOW & -6.0 & -0.05 & -219.3 & -86 & -7 & -68 & -1852 & -14340 & -13376 & -113 \\
\hline DSOW & -1.5 & -0.01 & -53.8 & -22 & -2 & -14 & -468 & -3529 & -3308 & -36 \\
\hline LDW & 0.9 & 0.01 & 32.6 & 21 & 1 & 44 & 220 & 2214 & 2069 & -2 \\
\hline Net & -0.4 & 0.69 & -0.8 & -50 & -6 & -26 & -1992 & -135 & -1081 & 116 \\
\hline
\end{tabular}

${ }^{\mathrm{a}} \mathrm{EGC}$ n.a., transport in the EGC not accounted for in the mixing analysis but attributed to the EGC $\mathrm{T}$; and Net, the net transport across the section.

[76] A portion of the water column along the $4 \mathrm{x}$ section was not characterized within the mixing analysis performed, those samples are comprised within the upper thermocline (upper 200 dbar as a mean) affected by seasonal changes and the last three stations near Cape Farewell affected by ice melting. In order to balance our transports we assume that the permanent thermocline water mass composition approximates the winter mixed layer. Thus the first shallower sample mixing composition from each station is extrapolated to the upper most water column. The transports in the nearest stations to Cape Farewell within the EGC are included in the $\mathrm{EGC}_{\mathrm{T}}$ contribution. Additionally the Ekman transports are attributed to ENACW. Note that the contribution of the ENACW subpolar and subtropical varieties was summed up in Table 3. As the mixing model calculates the fraction of pure SWTs (Table 1) in each water sample, the values given in Table 3 represent the contribution of each pure SWT to the total transport of any property. This procedure provides more information than the usual transports by isopycnic levels as the contribution of each water mass is given for the whole water column. Having the transport for each water mass in the different levels and some information about its sources, new insights about circulation patterns and water mass transformation can be inferred.

[77] A schematic representation of the regional and vertical transports across the $4 \mathrm{x}$ section within the context of the North Atlantic ocean is shown in Figure 9. The 4x line acts as the zero reference line, and the SWT contributions are represented as stacked bars. Note that the deep and bottom layer contributions are summed in Figure 9c.

[78] The transport of ENACW across the subpolar North Atlantic is centered in the upper layer and mainly concentrated in the NAC system (regions 4, 5, and 6; Figure 9a), with a total contribution of $10.3 \mathrm{~Sv}$ NE (Table 3). The ENACW contribution to the heat and $\mathrm{C}_{\mathrm{ANT}}$ transport is $0.60 \mathrm{PW}$ and $484 \mathrm{kmol} \mathrm{s}^{-1}$, thus ENACW is the main carrier of heat and $\mathrm{C}_{\mathrm{ANT}}$ toward the polar seas across the subpolar gyre. As well, ENACW has an important but not deterministic role in the NE transport of nutrients, $\mathrm{O}_{2}$, TA and TIC, because the total net transport of these properties is directed SW (Table 3).

[79] SAIW and AA are, as ENACW, mainly transported in the upper layer (Figure 9). The total transport of SAIW across the section is $2.9 \mathrm{~Sv}$ (Table 3), mostly within the NAC (region 5; Figure 9a). Consequently, the transport of physical and biogeochemical properties associated to this water mass is NE (Table 3 ). The maximum contribution of AA $(40 \%)$ was found in the NAC region (Figure 5). Accordingly, the largest AA transport is concentrated in this region and practically accounts for the total AA transport across the $4 \mathrm{x}$ section, amounting to $5.6 \mathrm{~Sv} \mathrm{NE}$ (Figure 9 and Table 3). This figure compares with the $5 \mathrm{~Sv}$ proposed by Schmitz [1996] of remnant upper AAIW transported within the NAC in his review about the North Atlantic ocean circulation.

[80] The cold and fresher $\mathrm{EGC}_{\mathrm{T}}$ is transported southward in the EGC to a total of $-5.4 \mathrm{~Sv}$ contributing to the export of nutrients, TA and TIC from the subpolar to the subtropical North Atlantic.

[81] A total of 1.7 Sv of MW flow northward across the $4 \mathrm{x}$ section, mainly at the upper and intermediate layers of the Iberian Basin (regions 1 and 2; Figures 9a and 9b). In the context of the global circulation, the $1.7 \mathrm{~Sv}$ of MW flowing into the subpolar gyre positively compare with the $1 \mathrm{~Sv}$ proposed by Schmitz [1996] in his review work.

[82] Despite its theta and salinity maximum, the relevance of MW in the transport of heat and salt across the $4 \mathrm{x}$ section is small (Table 3 ). In contrast, its contribution to the NE transport of TA, TIC and $\mathrm{C}_{\mathrm{ANT}}$ is remarkable. MW is characterized by extremely high values of TA and TIC, and a relative high $\mathrm{C}_{\mathrm{ANT}}$ value. Although formed from a very old water mass, the Mediterranean Outflow, with a residence time of about 70 years in the Mediterranean Sea [Pickard and Emery, 1990], the Outflow entrains central waters recently formed with a high content of $\mathrm{C}_{\mathrm{ANT}}$ in a 1:4 ratio. Concretely, Ríos et al. [2001] calculated that $185 \mathrm{kmol} \mathrm{s}^{-1}$ of $\mathrm{C}_{\mathrm{ANT}}$ are draw down to form $\mathrm{MW}$ in the

Figure 9. Stacked bars showing the regional mass transport across the $4 \mathrm{x}$ section accounted for by the different water masses: Eastern North Atlantic Central Water (ENACW), Subarctic Intermediate Water (SAIW), influenced Antarctic Intermediate Water (AA), East Greenland Current type $\left(\mathrm{EGC}_{\mathrm{T}}\right)$, Mediterranean Water (MW), Labrador Seawater (LSW), Iceland-Scotland Overflow Water (ISOW), Denmark Strait Overflow Water (DSOW), and North Eastern Atlantic Deep Water (NEADW) in (a) the upper, (b) the intermediate, and (c) the deep and bottom layers. Regions and density intervals are as in Figure 7. The $4 \mathrm{x}$ section acts as the zero reference line. $1 \mathrm{~Sv}=10^{6} \mathrm{~m}^{3} \mathrm{~s}^{-1}$. See color version of this figure at back of this issue. 

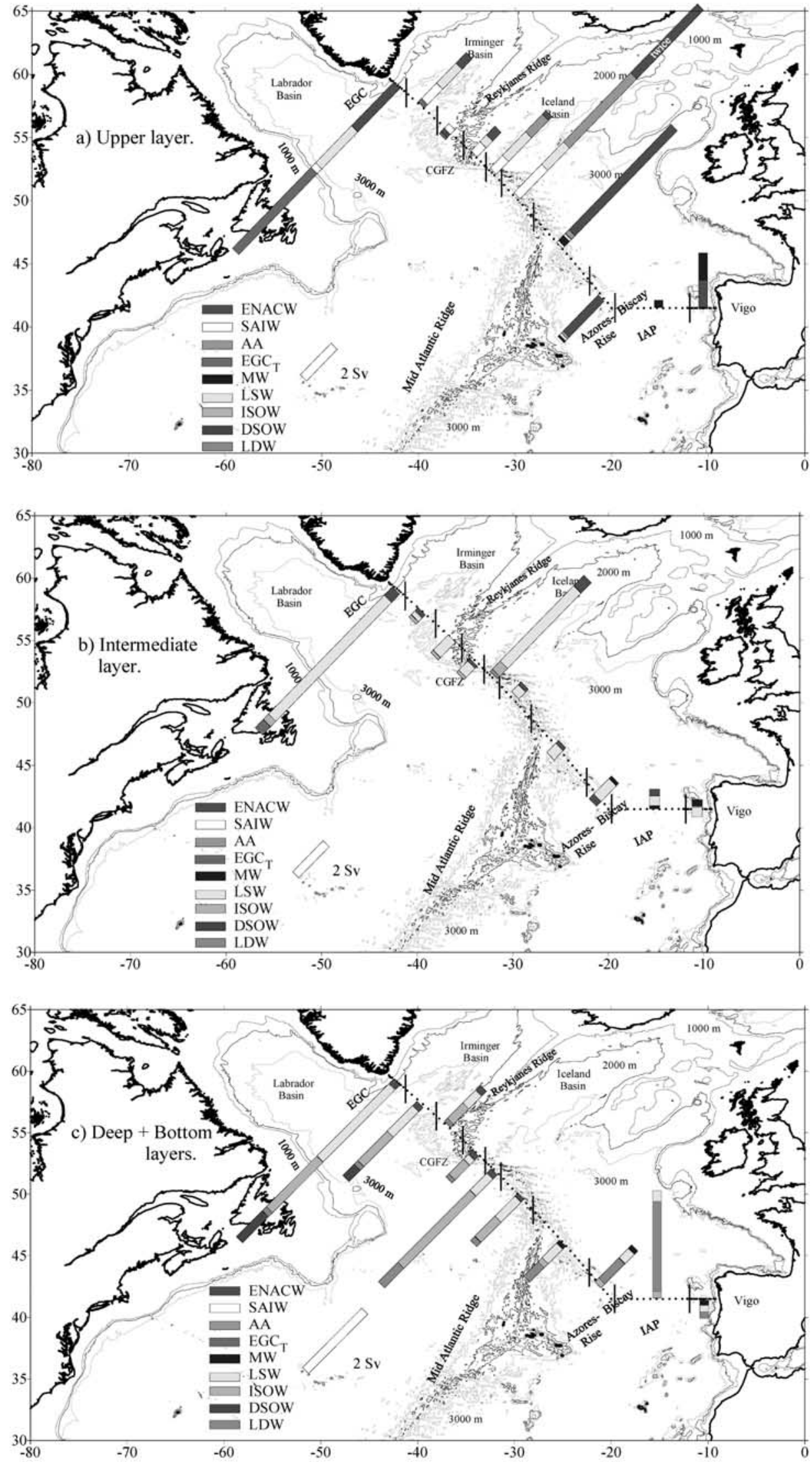

Figure 9. 
Gulf of Cádiz. According to our results $26 \%$ of this $\mathrm{C}_{\mathrm{ANT}}$ flows northward across $41.5^{\circ} \mathrm{N}$ in the Iberian Basin. This is a relevant mechanism for $\mathrm{C}_{\mathrm{ANT}}$ to be introduced to depth into the North Atlantic overturning circulation.

[83] The largest absolute transport across the $4 \mathrm{x}$ section is ascribed to LSW, $-8.8 \mathrm{~Sv}$ flow SW (Table 3), with a greater contribution from the intermediate layer $-5.8 \mathrm{~Sv}$ (Figure 9). In the upper layer, LSW is only transported west of the MAR (Figure 9a), where LSW is shallower (Figure 5). At this layer, 2.9 Sv of LSW flow NE within the NAC (regions 4, 5, and 6; Figure 9a), and $-2.3 \mathrm{~Sv}$ flow $\mathrm{SW}$ in the EGC, ending up with a slight NE transport of LSW at the upper layer of the $4 \mathrm{x}$ section. At the intermediate layer, LSW flows SW east of the MAR (region 4; Figure 9b), confirming the analysis by Paillet et al. [1998], who from salinity anomalies inferred a southward circulation of LSW-influenced water on the eastern flank of the MAR toward the Oceanographic Fracture Zone, to finally return to the western basin, in a kind of "Eastern Basin Deep Western Boundary Current".

[84] In accordance with the circulation scheme derived by Talley and McCartney [1982] from temperature and salinity distributions and by Paillet et al. [1998] from an inverse model in the eastern North Atlantic, $6.8 \mathrm{~Sv}$ of LSW cross the $4 \mathrm{x}$ section at the $49^{\circ}-54^{\circ} \mathrm{N}$ and $28^{\circ}-35^{\circ} \mathrm{W}$ band (regions 5 and 6; Figure 9b) toward the northeastern Atlantic. In the Reykjanes Ridge and Irminger Basin (regions 8 and 9, respectively) 1.2 Sv of LSW flow NE in the upper layer, whereas at the intermediate, deep and bottom layers the transport is $-1.6 \mathrm{~Sv}$. In the EGC (region 10) the whole water column transport of LSW amounts to $-12.3 \mathrm{~Sv}$, mainly centered at the intermediate layer $(-7.5 \mathrm{~Sv})$. The total EGC mass transport for the intermediate, deep and bottom layers amounts to $-14.8 \mathrm{~Sv}$, thus $83 \%$ of this flow is LSW, which will ultimately join the DWBC and determine the strength of the meridional overturning circulation.

[85] The net southward transport of LSW across the $4 x$ section is contradictory with the well established, but now changing, idea of LSW formation just in the Labrador Sea convection area. Our net southward transport implies a source of LSW north of the $4 \mathrm{x}$ section. In general, a warmer and saltier type of LSW is formed in the Irminger basin relative to the Labrador Sea but with the same density [Pickart et al., 2003]. During the low-NAO period from 1995 to $1998 \mathrm{LSW}$ around $2.9^{\circ} \mathrm{C}$ was formed in both basins. Consequently, our results suggest a southward transport of recently formed Irminger Sea LSW within the EGC toward the Labrador Sea, whereas LSW formed in the Labrador Sea crosses from the western to the eastern North Atlantic over the MAR and recirculates mainly northwestward and weakly southeastward in the Iberian basin in agreement with the results by Cunningham [2000].

[86] LSW constitutes the largest contributor to the export of nutrients, $\mathrm{O}_{2}$, TA, TIC and $\mathrm{C}_{\mathrm{ANT}}$ from the subpolar into the subtropical North Atlantic (Table 3). Despite this, the final net transport of some of the former properties can have an inverse sign, for example, the total transport of heat and $\mathrm{C}_{\mathrm{ANT}}$ is directed NE, because they are mainly transported in the upper layers with a higher temperature and $\mathrm{C}_{\mathrm{ANT}}$ (Figure 8).

[87] The total mass transport accounted for by ISOW is -6 Sv (Table 3), which mainly flows in the deep layer across the CGFZ, region 6, and the $\mathrm{EGC}$, region 10 , contributing with $-1.9 \mathrm{~Sv}$ and $-2.2 \mathrm{~Sv}$, respectively (Figure 9c). Note the small NE transport of ISOW in the intermediate layer over the CGFZ $(0.5 \mathrm{~Sv})$ indicating a return flow of ISOW from the western to the eastern basin, as proposed by Fleischmann et al. [2001].

[88] In the context of the global thermohaline circulation these $-6 \mathrm{~Sv}$ of ISOW flowing into the western basin are higher than the $-4 \mathrm{~Sv}$ proposed in the review by Schmitz [1996] of entrained overflow water from the Norwegian Sea, which will also ultimately join the DWBC. As for LSW, ISOW also exerts a relevant role in the export of nutrients, $\mathrm{O}_{2}$, TA, TIC and $\mathrm{C}_{\mathrm{ANT}}$ from the subpolar to the subtropical North Atlantic (Table 3).

[89] The other overflow from the Nordic Seas, the DSOW, crosses the $4 \mathrm{x}$ section in the Irminger Basin (regions 9 and 10; Figure 9c) mainly within the EGC over the western flank of the basin. DSOW accounts for a total of $-1.5 \mathrm{~Sv}$ flowing southward (Table 3 ). The contribution of DSOW to the export of nutrients, $\mathrm{O}_{2}, \mathrm{TA}$, TIC and $\mathrm{C}_{\mathrm{ANT}}$ from the subpolar to the subtropical North Atlantic is remarkable but much less than the ISOW contribution (Table 3).

[90] LDW contributes with $2 \mathrm{~Sv}$ flowing northward in the Iberian Abyssal Plain (region 2; Figure 9c), which correspond, as previously said, to Antarctic Bottom Water entering the eastern basin through the Vema Fracture. A portion $(-0.3 \mathrm{~Sv})$ of this northward flow returns southward within the eastern basin, whereas over the CGFZ, $-0.7 \mathrm{~Sv}$ of LDW enter the western basin (region 5 and 6, respectively; Figure 9c). The circulation pattern of LDW inferred from our results confirms the circulation scheme proposed by McCartney [1992] at the $2500 \mathrm{~m}$ layer. The net transport of LDW across the 4x section is $0.9 \mathrm{~Sv}$, which accounts for a small NE transport of heat and salt. Despite the high concentrations of nutrients at depth the contribution of LDW the NE transport of nutrients is relatively small, as well as for $\mathrm{O}_{2}$, TA, TIC and $\mathrm{C}_{\text {ANT }}$ (Table 3).

[91] Further information and some modifications can be added to the circulation scheme proposed by Schmitz [1996] for waters colder than $4{ }^{\circ} \mathrm{C}$ in the subpolar North Atlantic [Schmitz, 1996, front cover illustration]. In the Iberian Basin $3 \mathrm{~Sv}$ flow northward (Figure 10) and consist on 2.6 Sv of LDW and $0.4 \mathrm{~Sv}$ of recirculating ISOW. Within the eastern basin in the eastern flank of the MAR, $2 \mathrm{~Sv}$ return southward with a $65 \%$ of LSW, $20 \%$ of LDW, $10 \%$ of ISOW and $5 \%$ of MW. Crossing the CGFZ from the western to the eastern North Atlantic, we calculated $2 \mathrm{~Sv}$ of LSW, whereas $3 \mathrm{~Sv}$ of ISOW and $1 \mathrm{~Sv}$ of LDW cross to the western basin. Within the Irminger basin $18 \mathrm{~Sv}$ flow southwestward, composed by $66 \%$ LSW, $16 \%$ ISOW, $8 \%$ DSOW, 5\% ENACW, 3\% $\mathrm{EGC}_{\mathrm{T}}$ and $2 \%$ LDW. Keeping the numbers for the overflow production in the Nordic Seas given by Schmitz [1996] we need an entrainment of $14 \mathrm{~Sv}$ of warm waters into this temperature layer. Accordingly, on the basis of Figure I-21 from Schmitz [1996] or the back cover illustration, the upper level circulation in the subpolar North Atlantic (waters warmer than $7^{\circ} \mathrm{C}$; figure not shown here) can be complemented and modified. Within the NAC we obtained a transport of $20 \mathrm{~Sv}$ comprising 70\% ENACW, $19 \%$ AA (so about $5 \%$ of pure AAIW), $9 \%$ SAIW and $2 \%$ LSW, additionally $1 \mathrm{~Sv}$ of MW flow northward. No net 


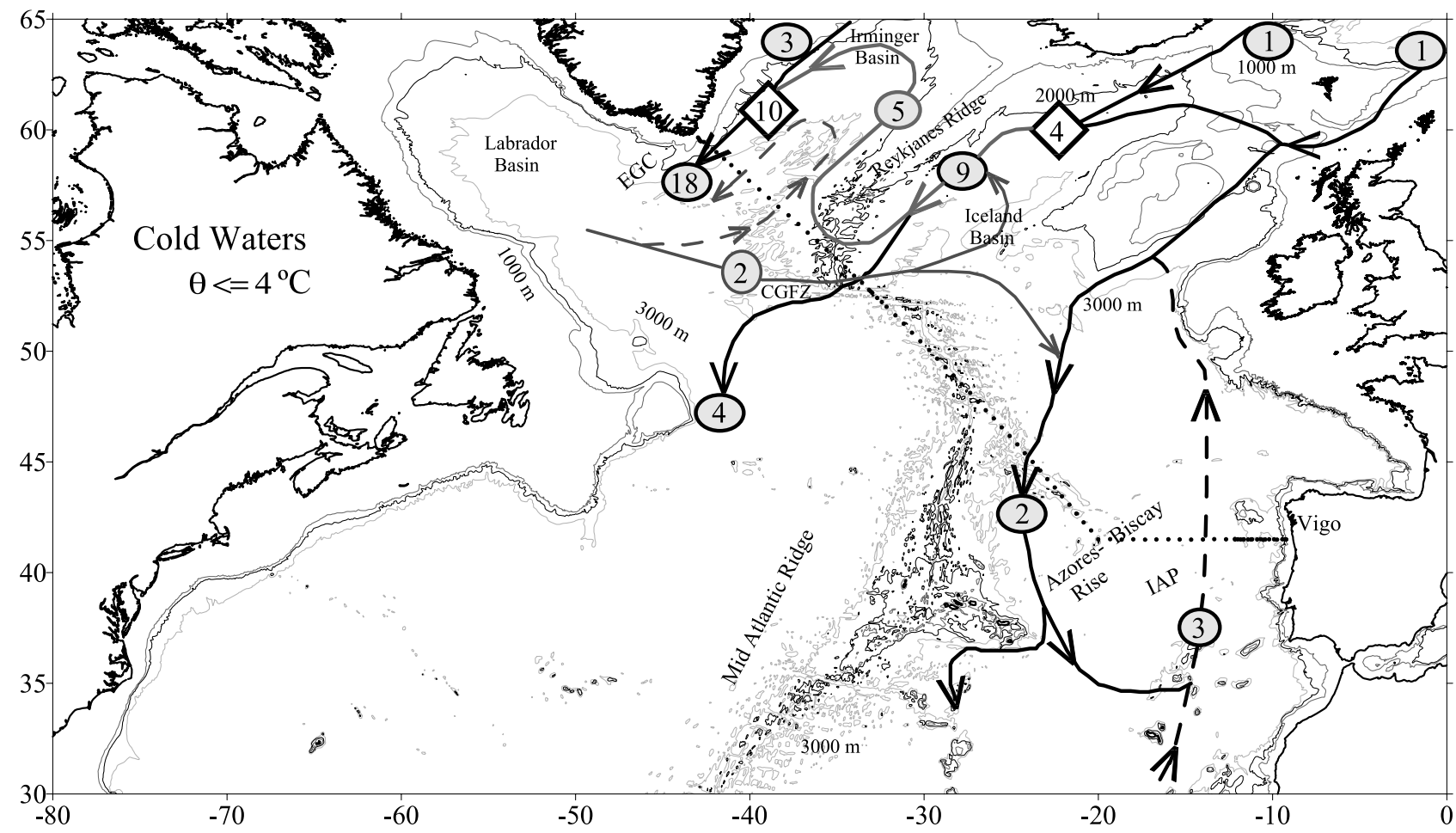

Figure 10. Schematic circulation in the North Atlantic subpolar gyre for waters colder than $4^{\circ} \mathrm{C}$. This figure is based on the front cover illustration of Schmitz [1996]. Accordingly, the shaded line (green by Schmitz) is the circulation scheme for generic North Atlantic Deep Water (NADW), black (dark blue) lines and symbols denote bottom water, dashed lines indicate slow water mass modification of Antarctic Bottom Water, and dark shaded lines denote the circulation of Labrador Seawater from the Labrador Sea. The dark shaded dashed line denotes the Irminger route for $1 \mathrm{~Sv}$ of pure LSW. Circles represent transports, and diamonds represent entrainment, both in sverdrups. $1 \mathrm{~Sv}=10^{6} \mathrm{~m}^{3} \mathrm{~s}^{-1}$.

transport was obtained within the Irminger basin. Therefore, if $5 \mathrm{~Sv}$ are transported into the Nordic Seas according to Schmitz [1996], $16 \mathrm{~Sv}$ of warm water should be converted to cold water within the subpolar gyre.

[92] The proposed circulation schemes are dependent on the mass constraints used in the determination of the velocity field; among them the volume flux in the EGC arises as one of the main sources of uncertainty. Because of the EGC high value changing it will considerably alter the circulation across the 4x section [Álvarez et al., 2002].

[93] For Álvarez et al. [2002], $15 \mathrm{~Sv}$ of upper waters (less than 1100 dbar) flow northward within the baroclinic or overturning circulation. In the present work we obtained a northward flow of $21 \mathrm{~Sv}$ of warm waters $\left(>7^{\circ} \mathrm{C}\right)$ within the NAC with no return flow southward within the EGC. Additionally, the $7^{\circ} \mathrm{C}$ isotherm is always above $1100 \mathrm{dbar}$; therefore there is an excess of $6 \mathrm{~Sv}$ of warm waters not contributing to the overturning circulation (from the vertical point of view) but contributing to the heat pump as they are converted within the subpolar gyre to colder waters. This excess of warm waters flows within the NAC and return colder at the same depth level in the upper 1100 dbar within the EGC, thus they are included in the horizontal circulation.

[94] The main differences between our circulation scheme for cold waters and that given by Schmitz [1996] are the magnitude of the EGC (he reports $14 \mathrm{~Sv}$ and we give $18 \mathrm{~Sv}$ ) and the Labrador Seawater circulation incorporation mechanism and contribution to the NADW formation (he reports
$4 \mathrm{~Sv}$ of LSW added by sinking to the cold water layer, while we calculated $2 \mathrm{~Sv}$ of LSW flowing from the western to the eastern basin at the cold water level).

[95] According to the present work the magnitude of the warm-to-cold water conversion within the subpolar gyre is $21 \mathrm{~Sv}$, a fraction of $15 \mathrm{~Sv}$ are transported within the overturning circulation so they flow northward in the upper 1100 dbar and back southward at a deeper level, whereas $6 \mathrm{~Sv}$ are converted within the horizontal cell, transported northward within the NAC and back southward within the EGC. Additionally, we propose the Irminger sea as an important area of warm-to-cold water conversion where about $10 \mathrm{~Sv}$ of warmer than $4^{\circ} \mathrm{C}$ water are converted to water with characteristics very similar to the LSW type. These waters flow within the EGC probably toward the Labrador Sea where they will acquire more extreme characteristics.

\section{Summary and Conclusions}

[96] Hydrographic and chemical data from the WOCE A25 (4x cruise) allowed us to estimate the transport of physical and chemical properties across the southern boundary of the subpolar North Atlantic ocean. The circulation pattern across the $4 \mathrm{x}$ section was approximated constraining the mass transport at specific areas and levels with literature available transport values. Furthermore, an inverse model was set in order to conserve the salt and mass transports 
across the section as we considered the North Atlantic ocean a closed basin, and also to force the silicate transport to its river input north of the section [Tréguer et al., 1995]. The water mass structure along the $4 \mathrm{x}$ section was solved by means of an extended Optimum MultiParameter analysis, considering $\theta, \mathrm{S}$ and $\mathrm{SiO}_{4}$ as conservative tracers and $\mathrm{NO}_{3}$, $\mathrm{PO}_{4}$, and $\mathrm{O}_{2}$ as nonconservative. Oxygen consumption from saturation conditions modeled biological processes and was related to $\mathrm{NO}_{3}$ and $\mathrm{PO}_{4}$ with the Anderson and Sarmiento [1994] Redfield ratios. The mixing along the section was solved using eleven SWT and additional mixing constraints which were proved to be reliable as the model is able to reproduce the physical and chemical fields along the section with a high degree of confidence.

[97] The circulation in the subpolar North Atlantic is ultimately related with the overturning cell: warm upper waters flow northward and return southward colder. The warm-to-cold water conversion within the subpolar gyre is estimated in $21 \mathrm{~Sv}$, a fraction of $15 \mathrm{~Sv}$ flow northward in the upper $1100 \mathrm{dbar}$ and return southward at deeper levels. The remaining $6 \mathrm{~Sv}$ are converted within the horizontal cell, transported northward in the North Atlantic Current and back southward in the East Greenland Current.

[98] The mixing structure along the section was combined with the transport fields in order to provide the relative contribution from each water mass to the transports across the section, as well as the water mass spatial circulation pattern across the section. The water masses contributing to a NE mass transport are ENACW, AA, MW and SAIW with 10.3, 5.6, 1.7 and $2.9 \mathrm{~Sv}$ respectively. The 5.6 Sv of influenced AAIW flowing NE across our section within the NAC agree with the 5 Sv proposed by Schmitz [1996] in his review. This author also proposed about $1 \mathrm{~Sv}$ of MW incorporated into the North Atlantic Deep Water formation complex. This value agrees with our estimation $(1.7 \mathrm{~Sv})$.

[99] The total flux of LDW across the $4 \mathrm{x}$ section is $\approx 1 \mathrm{~Sv}$ northward. A portion of the $2 \mathrm{~Sv}$ of LDW flowing northward east of the Azores-Biscay Rise recirculate in the eastern basin, 0.3 Sv, and about $0.7 \mathrm{~Sv}$ flow $\mathrm{SW}$ into the western basin.

[100] Waters contributing to a net SW flow across the section are LSW (-9 Sv) and the overflows, DSOW $(-1.5 \mathrm{~Sv})$ and ISOW $(-6 \mathrm{~Sv})$ and surface water in the EGC $(-5.4 \mathrm{~Sv})$ from the Arctic seas. About $7 \mathrm{~Sv}$ of LSW from the Labrador Sea flow NE across the $4 \mathrm{x}$ section in the NAC area but on the other hand $-12 \mathrm{~Sv}$ of LSW in the Irminger basin flow SW in the EGC. Supporting the formation of LSW in the Irminger Sea [Bacon et al., 2003; Pickart et al., 2003]. DSOW flows SW over the western flank of the Irminger basin and ISOW mainly over the CGFZ area, remnants of ISOW flow SW in the eastern basin indicating its contribution to the eastern basin ventilation. The subpolar North Atlantic north of the 4x section exports nutrients, oxygen and TIC. Nutrients and oxygen are mainly carried SW by LSW and the overflows. As waters recently formed they have a high oxygen content, in fact higher than the section mean oxygen value. Thus the combination of a SW mass transport at a differential high value of oxygen leads to the relative positive contribution to the export of oxygen from the subpolar North Atlantic. A similar but opposite argument can be applied to AA or MW: they are characterized by oxygen minima (lower than the section mean value) but flow NE; therefore, although they directly transport oxygen NE, this flow can be understood as an oxygen impoverishment north of the section. In the case of nutrients, the subpolar North Atlantic behaves as a net heterotrophic system [Álvarez et al., 2002] so waters recently formed as LSW or the overflows are loaded with nutrients and TIC prepared to be exported. $\mathrm{C}_{\mathrm{ANT}}$ is mainly carried NE by upper and intermediate waters (ENACW, AA, SAIW and MW) whose contribution exceeds the SW transport by deep waters as LSW, DSOW and ISOW or upper water in the EGC which are significantly loaded in $\mathrm{C}_{\text {ANT }}$. Thus the subpolar North Atlantic is accumulating $\mathrm{C}_{\mathrm{ANT}}$ and the main mechanism accounting for this accumulation is the overturning circulation [Álvarez et al., 2003].

[101] Acknowledgments. We are grateful to Sheldon Bacon, Principal Scientist, to the Captain, officers, and crew of RRS Discovery and to the science team for their hard work during the $4 \mathrm{x}$ cruise. The cruise was primarily supported by the Natural Environment Research Council (NERC) under the UK WOCE Community Research Program. Our special thanks to Iris Soler Arístegui for her valuable help and support with the analysis and sampling during the cruise. Spanish participation was funded by the Spanish CICYT project MAR-97-1622-E. The stay of M. Álvarez at SOC was financed by a "Beca de estancia no estranxeiro" and a "Beca Predoutoral" from the Xunta de Galicia.

\section{References}

Álvarez, M., H. L. Bryden, F. F. Pérez, A. F. Ríos, and G. Rosón (2002), Physical and biogeochemical fluxes and net budgets in the subpolar and temperate North Atlantic, J. Mar. Res., 60, 191-226.

Álvarez, M., A. F. Ríos, F. F. Pérez, H. L. Bryden, and G. Rosón (2003), Transports and budgets of total inorganic carbon in the subpolar and temperate North Atlantic, Global Biogeochem. Cycles, 17(1), 1002, doi:10.1029/2002GB001881.

Ambar, I., and M. R. Howe (1979), Observations of the Mediterranean outflow-I: Mixing in the Mediterranean outflow, Deep Sea Res., Part A, $26,535-554$.

Anderson, L. A., and J. L. Sarmiento (1994), Redfield ratios of remineralization determined by nutrient data analysis, Global Biogeochem. Cycles, 8, 65-80.

Arhan, M. (1990), The North Atlantic Current and Subarctic Intermediate Water, J. Mar. Res., 48, 109-144.

Arhan, M., and B. King (1995), Lateral mixing of the Mediterranean Water in the eastern North Atlantic, J. Mar. Res., 53, 865-895.

Arhan, M., A. Colin de Verdière, and H. Mercier (1989), Direct observations of the mean circulation at $48^{\circ} \mathrm{N}$ in the Atlantic Ocean, J. Phys. Oceanogr., 19, 161-181.

Arhan, M., A. Colin de Verdière, and L. Memery (1994), The eastern boundary of the subtropical North Atlantic, J. Phys. Oceanogr., 24, $1295-1316$.

Bacon, S. (1997), Circulation and fluxes in the North Atlantic between Greenland and Ireland, J. Phys. Oceanogr., 27, 1420-1435.

Bacon, S. (1998), RRS Discovery cruise 230, 07 Aug-17 Sep 1997. Two hydrographic sections across the boundaries of the Subpolar Gyre: FOUREX, Southampton Oceanogr. Cent. Cruise Rep. 16, 104 pp., Southampton, U.K.

Bacon, S., W. J. Gould, and Y. Jia (2003), Open-ocean convection in the Irminger Sea, Geophys. Res. Lett., 30(5), 1246, doi:10.1029/ 2002GL016271.

Bersch, M. (1995), On the circulation of the northeastern North Atlantic, Deep Sea Res., Part I, 42, 1583-1607.

Brewer, P. G. (1978), Direct observations of the oceanic $\mathrm{CO}_{2}$ increase, Geophys. Res. Lett., 5, 997-1000.

Bryden, H. L., and S. Imawaki (2001), Ocean heat transport, in Ocean Circulation and Climate, Int. Geophys. Ser, vol. 77, edited by by G. Siedler, J. Church, and J. Gould, pp. 455-474, Academic, San Diego, Calif.

Bubnov, V. A. (1968), Intermediate subarctic waters in the northern part of the Atlantic Ocean, Okeanologia, 19, 136-153. (English translation, N00 Trnas 545, U.S. Nav. Oceanogr. Off., Washington, D. C., 1973).

Castro, C. G., F. F. Pérez, S. E. Holley, and A. F. Ríos (1998), Chemical characterisation and modelling of water masses in the Northeast Atlantic, Prog. Oceanogr., 41, 249-279.

Chen, C. T., and F. J. Millero (1979), Gradual increase of oceanic carbon dioxide, Nature, 277, 205-206. 
Clayton, T. D., and R. Byrne (1993), Spectrophotometric seawater pH measurements: Total hydrogen ion concentration scale calibration of $\mathrm{m}$ cresol purple and at-sea results, Deep Sea Res., Part I, 40, 2115-2129.

Culberson, C. H. (1991), WOCE operations manual (WHP operations and methods), WHPO 91/1, 15 pp., Woods Hole Oceanogr. Inst., Woods Hole, Mass

Cunningham, S. A. (2000), Circulation and volume flux of the North Atlantic using synoptic hydrographic data in a Bernoulli inverse, J. Mar. Res., 58, 1-35.

Cunningham, S. A., and T. W. N. Haine (1995), Labrador Sea Water in the eastern North Atlantic. part I: A synoptic circulation inferred from a minimum in potential vorticity, J. Phys. Oceanogr., 25, 649-665.

Dickson, A. G. (1981), An exact definition of total alkalinity and a procedure for the estimation of alkalinity and inorganic total carbon from titration data, Deep Sea Res., Part A, 28, 609-623.

Dickson, R., and J. Brown (1994), The production of North Atlantic Deep Water: Sources, rate and pathways, J. Geophys. Res., 99, 12,319-12,341. Dooley, H. D., and J. Meincke (1981), Circulation and water masses in the Faroese Channels during Overflow' 73, D. Hydrogr. Z., 34, 41-54.

Ellett, D. J., and J. H. A. Martin (1973), The physical and chemical oceanography of the Rockall Channel, Deep Sea Res., 20, 585-625.

Fahrbach, E., W. Krauss, J. Meincke, and A. Sy (1985), Nordostatlantic '84-data report, in Berichte aus dem Institut für Meereskunde, vol. 134, 60 pp., Kiel, Germany.

Fiúza, A. F. G. (1984), Hidrologia e dinâmica das águas costeriras de Portugal, Ph.D. diss., 294 pp., Univ. de Lisboa, Lisbon, Portugal.

Fleischmann, U., H. Hildebrandt, A. Putzka, and R. Bayer (2001), Transport of newly ventilated deep water from the Iceland Basin to the Westeuropean Basin, Deep Sea Res., Part I, 48, 1793-1819.

Fraga, F., C. Mouriño, and M. Manríquez (1982), Las masas de agua en la costa de Galicia: Junio-Octubre, Result. Exped. Cient., 10, 51-77.

Fraga, F., E. D. Barton, and O. Llinás (1985), The concentration of nutrient salts in "pure" North and South Atlantic Central Waters, paper presented at Simposio Internacional sobre las Areas de Afloramiento más importantes del Oeste Africano, Inst. de Invest. Pesqueras, Montevideo, Uruguay.

Gruber, N., J. L. Sarmiento, and T. F. Stocker (1996), An improved method for detecting anthropogenic $\mathrm{CO}_{2}$ in the oceans, Global Biogeochem Cycles, 10, 809-837.

Harvey, J. (1982), $\theta-\mathrm{S}$ relationship and water masses in the eastern North Atlantic, Deep Sea Res., Part A, 29, 1021-1033.

Harvey, J., and M. Arhan (1988), The water masses of the central North Atlantic in 1983-84, J. Phys. Oceanogr., 18, 1855-1875.

Harvey, J. G., and A. Theodorou (1986), The circulation of Norwegian Sea overflow water in the eastern North Atlantic, Oceanol. Acta, 9, 393-402.

Holfort, J., K. M. Johnson, B. Scheider, G. Siedler, and D. W. R. Wallace (1998), Meridional transport of dissolved inorganic carbon in the South Atlantic Ocean, Global Biogeochem. Cycles, 12, 479-499.

Iselin, C. O. (1936), A study of the circulation of the western North Atlantic, Pap. Phys. Oceanogr., 4, $101 \mathrm{pp}$

Karstensen, J., and M. Tomczak (1998), Age determination of mixed water masses using CFC and oxygen data, J. Geophys. Res., 103, 18,59918,610 .

Körtzinger, A., L. Mintrop, and J. C. Duinker (1998), On the penetration of anthropogenic $\mathrm{CO}_{2}$ into the North Atlantic Ocean, J. Geophys. Res., 103, $18,681-18,689$

Krauss, W. (1986), The North Atlantic Current, J. Geophys. Res., 91, $5061-5074$

Krauss, W. (1995), Currents and mixing in the Irminger Sea and in the Iceland Basin, J. Geophys. Res., 100, 10,851-10,871.

Lee, A., and D. J. Ellett (1967), On the water masses of the northwest Atlantic Ocean, Deep Sea Res., 14, 183-190.

Maillard, C. (1984), Mean circulation and exchanges in the northeastern Atlantic from historic data, J. Cons. Int. Explor. Mer., 185, 127-135.

Mann, C. R. (1969), Temperature and salinity characteristics of the Denmark Strait overflow, Deep Sea Res., 16, 125-137.

Mann, C. R., A. R. Coote, and D. M. Garner (1973), The meridional distribution of silicate in the western Atlantic Ocean, Deep Sea Res. Part I, 20, 791-801

Mantyla, A. W. (1994), The treatment of inconsistencies in Atlantic deep water salinity data, Deep Sea Res., 41, 1387-1405.

Martel, F., and C. Wunsch (1993), The North Atlantic circulation in the early 1980s-an estimate from inversion of a finite difference model, J. Phys. Oceanogr., 29, 283-383.

Mauritzen, C. (1996), Production of dense overflow waters feeding the North Atlantic across the Greenland-Scotland Ridge. Part 1: Evidence for a revised circulation scheme, Deep Sea Res., Part I, 43, 769-806.

Mazé, J. P., M. Arhan, and H. Mercier (1997), Volume budget of the eastern boundary layer off the Iberian Peninsula, Deep Sea Res., Part I, 44, $1543-1574$.
McCartney, M. S. (1977), Subantarctic mode water, in A Voyage of Discovery: George Deacon 70th Anniversary Volume, Deep Sea Res., 24, $103-119$

McCartney, M. S. (1982), The subtropical recirculation of mode waters, J. Mar. Res., 40, 427-464.

McCartney, M. S. (1992), Recirculating components of the deep boundary current of the northern North Atlantic, Prog. Oceanogr., 29, 283-383.

McCartney, M. S., and L. D. Talley (1982), The subpolar mode water of the North Atlantic Ocean, J. Phys. Oceanogr., 12, 1169-1188.

McCartney, M. S., S. L. Bennett, and M. E. Woodgate-Jones (1991), Eastward flow through the Mid-Atlantic Ridge at $11^{\circ} \mathrm{N}$ and its influence on the abyss of the eastern basin, J. Phys. Oceanogr., 14, 922-935.

Mehrbach, C., C. H. Culberson, J. E. Hawley, and R. M. Pytlowicz (1973), Measurements of the apparent dissociation constant of carbonic acid in seawater at atmospheric pressure, Limnol. Oceanogr., 18, 897-907.

Metcalf, W. G. (1969), Dissolved silicate in the deep North Atlantic, Deep Sea Res., 16, 1396-1450.

Orr, J. C., et al. (2001), Estimates of anthropogenic carbon uptake from four three-dimensional global ocean models, Global Biogeochem. Cycles, 15, $43-60$.

Paillet, J., and H. Mercier (1997), An inverse model of the eastern North Atlantic general circulation and thermohaline ventilation, Deep Sea Res. Part I, 44, 1293-1328

Paillet, J., M. Arhan, and M. S. McCartney (1998), Spreading of Labrador Sea Water in the eastern North Atlantic, J. Geophys. Res., 103, 10,22310,239 .

Pérez, F. F., and F. Fraga (1987), A precise and rapid analytical procedure for alkalinity determination, Mar. Chem., 21, 169-182.

Pérez, F. F., C. Mouriño, F. Fraga, and A. F. Ríos (1993), Displacement of water masses and remineralization rates off the Iberian Peninsula by nutrient anomalies, J. Mar. Res., 51, 1-24.

Pérez, F. F., L. Mintrop, O. Llinás, M. Glez-Dávila, C. G. Castro, M. Alvarez, A. Koertzinger, M. Santana-Casiano, M. J. Rueda, and A. F. Ríos (2001), Mixing analysis of nutrients, oxygen and inorganic carbon in the Canary Islands region, J. Mar. Syst., 28, 183-201.

Pérez, F. F., M. Alvarez, and A. F. Ríos (2002), Improvements on the backcalculation technique for estimating anthropogenic $\mathrm{CO}_{2}$, Deep Sea Res., Part I, 49, 859-875.

Pickard, G. L., and W. J. Emery (1990), Descriptive Physical Oceanography. An Introduction, 5th ed., 320 pp., Pergamon, New York.

Pickart, R. S., F. Straneo, and G. W. K. Moore (2003), Is Labrador Sea Water formed in the Irminger basin?, Deep Sea Res., Part I, 50, 23-52.

Pingree, R. D. (1973), A component of Labrador sea water in the Bay of Biscay, Limnol. Oceanogr., 18, 711-718

Pollard, R. T., and S. Pu (1985), Structure and circulation of the upper Atlantic Ocean northeast of the Azores, Prog. Oceanogr., 14, 443-462. Pollard, R. T., M. J. Griffiths, S. Cunningham, J. F. Read, F. F. Pérez, and A. F. Ríos (1996), Vivaldi 1991 - A study of the formation, circulation and ventilation of eastern North Atlantic Central Water, Prog. Oceanogr., $37,167-192$

Poole, R., and M. Tomczak (1999), Optimum multiparameter analysis of the water mass structure in the Atlantic Ocean thermocline, Deep Sea Res., Part I, 46, 1895-1921.

Read, J. F., and D. J. Ellett (1991), Subarctic Intermediate Water in the eastern North Atlantic, ICES C.M. 1991/C:42, 11 pp., Int. Counc. for Explor. of the Sea, Copenhagen.

Reid, J. L. (1989), On the total geostrophic circulation of the South Atlantic Ocean: Flow, patterns, tracers and transports, Prog. Oceanogr., 23, 149244.

Reid, J. L. (1994), On the total geostrophic circulation of the North Atlantic Ocean: Flow, patterns, tracers and transports, Prog. Oceanogr., 33, 1-92. Reid, J. L., and R. Lynn (1971), On the influence of the Norwegian Greenland and Weddell Seas upon the bottom waters of the Indian and Pacific Oceans, Deep Sea Res., 18, 1063-1088.

Rintoul, S. R., and C. Wunsch (1991), Mass, heat, oxygen and nutrient fluxes and budgets in the North Atlantic Ocean, Deep Sea Res., Part A, $38,355-377$

Ríos, A. F., F. F. Pérez, and F. Fraga (1992), Water masses in the upper and middle North Atlantic Ocean east of the Azores, Deep Sea Res., Part A, 39, 645-658

Ríos, A. F., and G. Rosón (1996), Surface $\mathrm{pH}$, alkalinity and $\mathrm{pCO}_{2}$ measurements, in Recueil de Données par Le Groupe CITHER-2, vol. 3, pp. 64-72, Lab. de Phys. des Océans, Brest, France.

Ríos, A. F., F. F. Pérez, and F. Fraga (2001), Long-term [1977-1997] measurements of carbon dioxide in the eastern North Atlantic: Evaluation of anthropogenic input, Deep Sea Res., Part II, 48, 2227-2239.

Rosón, G., A. F. Ríos, A. Lavín, F. F. Pérez, and H. L. Bryden (2003) Carbon distribution, fluxes and budgets in the Subtropical North Atlantic Ocean $\left(24.5^{\circ} \mathrm{N}\right)$, J. Geophys. Res., 108(C5), 3144, doi:10.1029/ 1999JC000047. 
Rossby, T. (1996), The North Atlantic Current and surrounding waters: At the crossroads, Rev. Geophys., 34, 463-481.

Sabine, C. L., R. M. Key, K. M. Johnson, A. Poisson, J. L. Sarmiento, D. W. R. Wallace, and C. D. Winn (1999), Anthropogenic $\mathrm{CO}_{2}$ inventory of the Indian Ocean, Global Biogeochem. Cycles, 13, 179-198.

Sarmiento, J. L., P. Monfray, E. Maier-Reimer, O. Aumont, R. J. Murnane, and J. C. Orr (2000), Sea-air $\mathrm{CO}_{2}$ fluxes and carbon transport: A comparison of three ocean general circulation models, Global Biogeochem. Cycles, 14, 1267-1281.

Saunders, P. M. (1982), Circulation in the eastern North Atlantic, J. Mar. Res., 40, 641-657.

Saunders, P. M. (1986), The accuracy of measurements of salinity, oxygen and temperature in the deep ocean, J. Phys. Oceanogr., 16, 189-195.

Saunders, P. M. (1987), Flow through Discovery Gap, J. Phys. Oceanogr, $17,631-643$.

Saunders, P. M. (1994), The flux of overflow water through the CharlieGibbs Fracture Zone, J. Geophys. Res., 99, 12,343-12,355.

Schmitz, W. J., Jr. (1996), On the world ocean circulation: vol. I, Some global features/North Atlantic circulation, Woods Hole Oceanogr. Inst. Tech. Rep. WHOI-96-03, Woods Hole, Mass.

Schmitz, W. J., and M. S. McCartney (1993), On the North Atlantic circulation, Rev. Geophys., 31, 29-49.

Stoll, M. H. C., H. M van Aken, H. J. W. de Baar, and M. Kraak (1996), Carbon dioxide characteristics of water masses in the northern North Atlantic Ocean, Mar. Chem., 55, 217-232.

Stommel, H., and B. Arons (1960), On the abyssal circulation of the world ocean II-An idealized model of the circulation pattern and amplitude in ocean basins, Deep Sea Res., 6, 217-233.

Strass, V. H., E. Fahrbach, U. Schauer, and L. Sellmann (1993), Formation of Denmark Strait Overflow Water by mixing in the East Greenland Current, J. Geophys. Res., 98, 6907-6919.

Suga, T., and L. D. Talley (1995), Antarctic Intermediate Water circulation in the tropical and subtropical South Atlantic, J. Geophys. Res., 100, $13,441-13,453$

Swift, J. H. (1984), The circulation of Denmark Strait and Iceland-Scotland overflow waters in the North Atlantic, Deep Sea Res, 31, 1339-1355.

Swift, J. H., K. Aagaard, and S. A. Malmberg (1980), The contribution of the Denmark Strait overflow water to deep North Atlantic, Deep Sea Res., Part A, 27, 29-42.

Sy, A. (1988), Investigation of large-scale circulation patterns in the centra North Atlantic: The North Atlantic Current, the Azores Current, and the Mediterranean Water plume in the area of the Mid-Atlantic Ridge, Deep Sea Res., Part A, 35, 383-413.

Sy, A., U. Schauer, and J. and Meincke (1992), The North Atlantic Current and its associated hydrographic structure above and eastwards of the Mid-Atlantic Ridge, Deep Sea Res., Part A, 39, 825-853.

Sy, A., M. Rhein, J. R. N. Lazier, K. P. Koltermann, J. Meincke, A. Putzka and M. Bersch (1997), Surprisingly rapid spreading of newly formed intermediate waters across the North Atlantic Ocean, Nature, 386, $675-679$

Talley, L. D., and M. S. McCartney (1982), Distribution and circulation of Labrador Sea Water, J. Phys. Oceanogr., 12, 1189-1205.

Tréguer, P., D. M. Nelson, A. J. van Bennekom, D. J. DeMaster, A. Laynaert, and B. Quéguiner (1995), The silicate balance in the world ocean: A reestimate, Science, 268, 375-379.

Tsuchiya, M. (1989), Circulation of the Antarctic intermediate water in the North Atlantic Ocean, J. Mar. Res., 47, 747-755.

Tsuchiya, M., L. D. Talley, and M. S. McCartney (1992), An eastern Atlantic section from Iceland southward across the equator, Deep Sea Res., Part A, 39, 1885-1917.

van Aken, H. M., and G. Becker (1996), Hydrography and through-flow in the north-eastern North Atlantic Ocean: The Nansen project, Prog. Oceanogr., 38, 297-346.

van Aken, H. M., and C. J. de Boer (1995), On the synoptic hydrography of intermediate and deep water masses in the Iceland Basin, Deep Sea Res., Part I, 42, 165-189.

van Aken, H. M., and D. Eisma (1987), The circulation between Iceland and Scotland derived form water mass analysis, Neth. J. Sea Res., 21, $1-15$.

Völker, C., D. W. R. Wallace, and D. A. Wolf-Gladrow (2002), On the role of heat fluxes in the uptake of anthropogenic carbon in the North Atlantic, Global Biogeochem. Cycles, 16, 1138, doi:10.1029/2003JC002015.

Wijffels, S. E. (2001), Ocean transport of freshwater, in Ocean Circulation and Climate, Int. Geophys. Ser., vol. 77, edited by G. Siedler, J. Church, and J. Gould, pp. 475-488, Academic, San Diego, Calif.

Worthington, L. V. (1976), On the North Atlantic Circulation, Johns Hopkins Oceanogr. Stud., 6, 110 pp.

Wüst, G. (1978), The Stratosphere of the Atlantic Ocean: Scientific Results fo the German Atlantic Expedition of the Research Vessel 'Meteor' 1925-27, translated from German by W. J. Emery, 112 pp., Amerind, Springfield, Va

Wüst, G., and A. Defant (1936), Atlas zur Schichtung und Zirculation des Atlantischen Ozeans. Schnitte und Karten von temperatur, salzgehalt und dichte, in Wissenschaftliche Ergebnisse der Deutcher Atlantischen Expedition aud der Forschungs und Vermessungsschiff "Meteor" 1925-1927, 6 Atlas, 103 plates.

Zenk, W. (1975), On the Mediterranean outflow west of Gibraltar, Meteor Forschungsergeb., Reihe A, 16, 23-24.

M. Álvarez, F. F. Pérez, and A. F. Ríos, Instituto de Investigaciones Marinas (CSIC), c $\backslash$ Eduardo Cabello, Nº, 36208, Vigo, Spain. (malvarez@ iim.csic.es)

H. Bryden, Southampton Oceanography Centre, Empress Dock, Southampton SO14 3ZH, United Kingdom. 
Figure 9. Stacked bars showing the regional mass transport across the $4 \mathrm{x}$ section accounted for by the different water masses: Eastern North Atlantic Central Water (ENACW), Subarctic Intermediate Water (SAIW), influenced Antarctic Intermediate Water (AA), East Greenland Current type $\left(\mathrm{EGC}_{\mathrm{T}}\right)$, Mediterranean Water (MW), Labrador Seawater (LSW), Iceland-Scotland Overflow Water (ISOW), Denmark Strait Overflow Water (DSOW), and North Eastern Atlantic Deep Water (NEADW) in (a) the upper, (b) the intermediate, and (c) the deep and bottom layers. Regions and density intervals are as in Figure 7. The 4x section acts as the zero reference line. $1 \mathrm{~Sv}=10^{6} \mathrm{~m}^{3} \mathrm{~s}^{-1}$. 

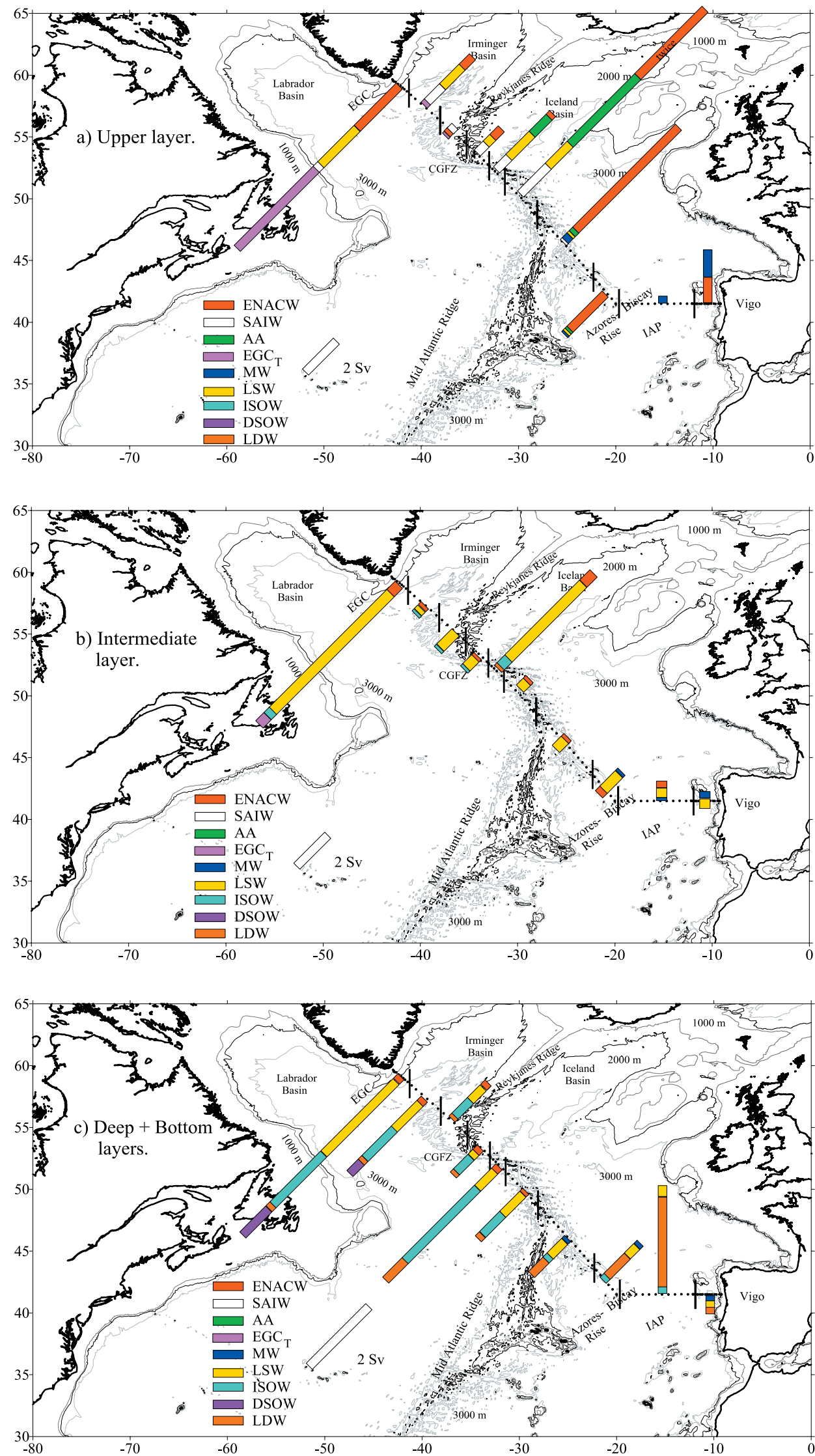

Figure 9. 